\title{
Mover
}

COMPUTER SCIENCES DIVISION

\section{SCOPE: \\ SYNERGISTIC COMPUTER OPTIMIZATION OF PLANNING FOR ENRICHMENT}

STATUS REPORT

\author{
R. C. DeLoziır \\ D. M. Kelleher \\ K. E. Cross
}

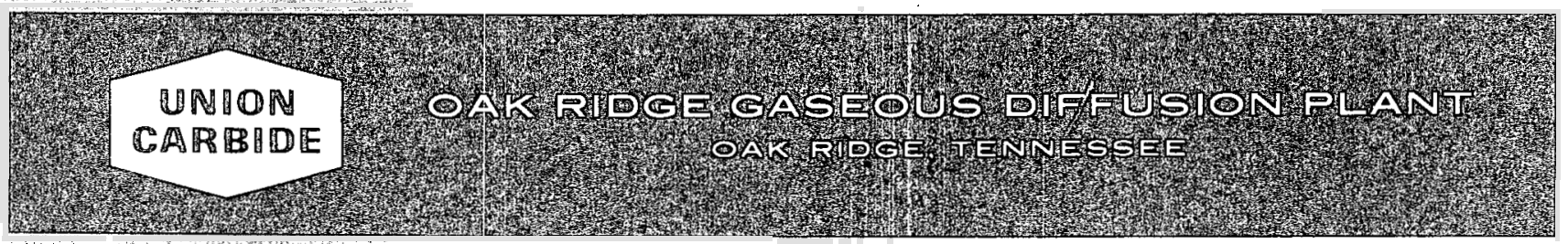

prepared for the U.S. ENERGY RESEARCH AND DEVELOPMENT ADMINISTRATION under U.S. GOVERAMENT Contract W.7405 eng 26 
$$
\text { . }
$$ 


\section{DISCLAIMER}

This report was prepared as an account of work sponsored by an agency of the United States Government. Neither the United States Government nor any agency Thereof, nor any of their employees, makes any warranty, express or implied, or assumes any legal liability or responsibility for the accuracy, completeness, or usefulness of any information, apparatus, product, or process disclosed, or represents that its use would not infringe privately owned rights. Reference herein to any specific commercial product, process, or service by trade name, trademark, manufacturer, or otherwise does not necessarily constitute or imply its endorsement, recommendation, or favoring by the United States Government or any agency thereof. The views and opinions of authors expressed herein do not necessarily state or reflect those of the United States Government or any agency thereof. 


\section{DISCLAIMER}

Portions of this document may be illegible in electronic image products. Images are produced from the best available original document. 
Contract No. $W-7405$ eng 26

COMPUTER SCIENCES DIVISION

\begin{abstract}
SCOPE
SYNERGISTIC COMPUTER OPTIMIZATION OF PLANNING

FOR ENRICHMENT
\end{abstract}

STATUS REPORT

\author{
R. C. DeLozier \\ D. M. Kelleher \\ K. E. Cross \\ Computing Applications Department
}

Ju1y, 1977

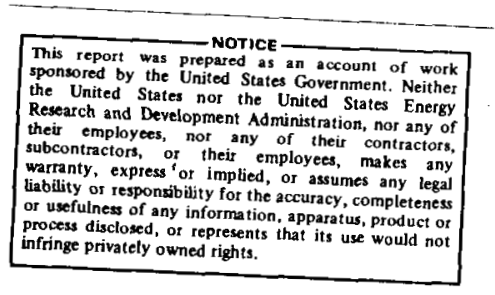

UNION CARBIDE CORPORATION, NUCLEAR DIVISION operating the

Oak Ridge Gaseous Diffusion Plant . Oak Ridge National Laboratory

Oak Ridge Y-12 Plant

- Paducah Gaseous Diffusion Plant for the

ENERGY RESEARCH AND DEVELOPMENT ADMINISTRATION 
TABLE OF CONTENTS

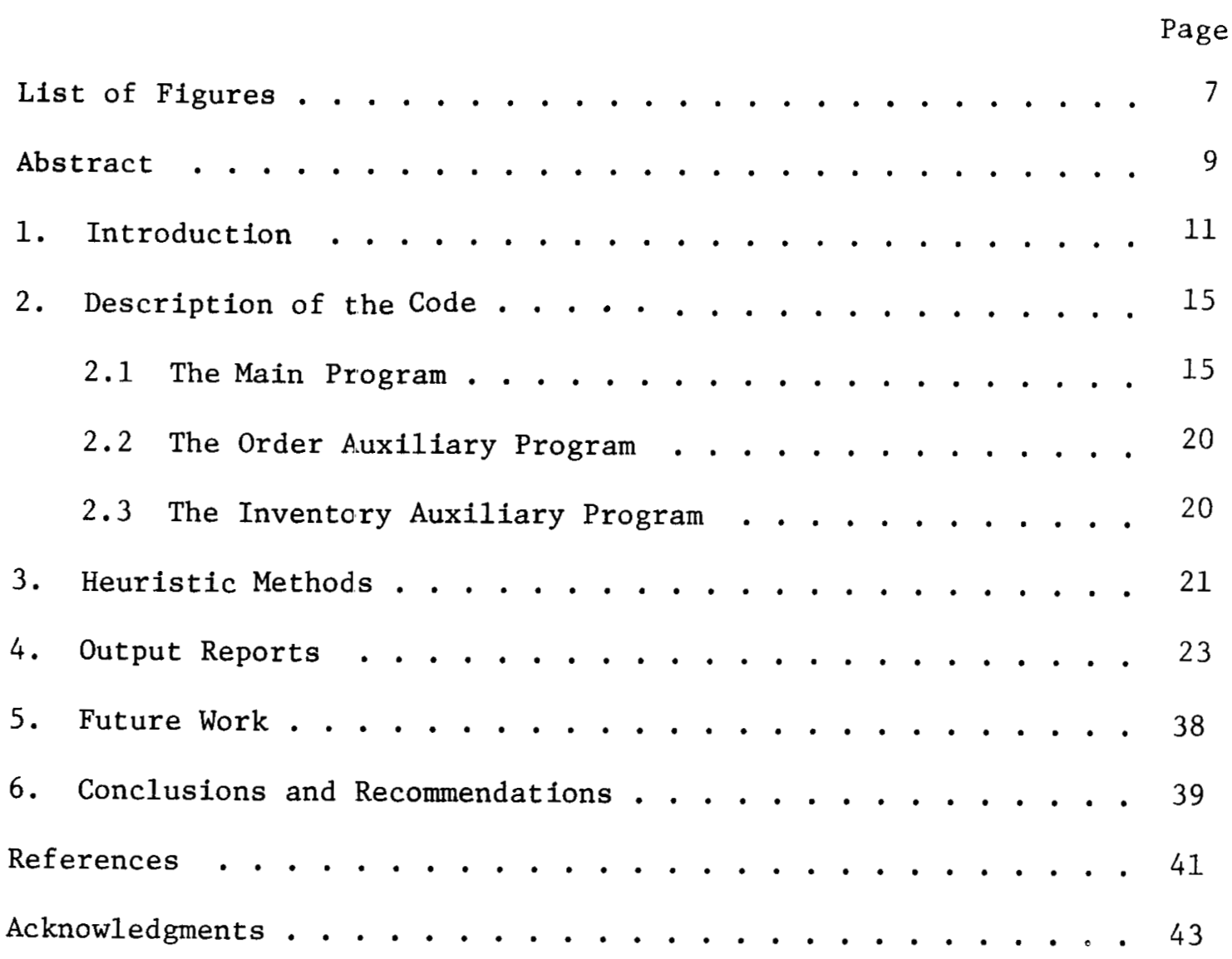



LIST OF FIGURES

Figure

Page

1 Illustration of SCOPE Package . . . . . . . . . 13

2 Cascade Model .................. 17

3 Example of Separative Capacity Versus Power 19

4 Example of Daily Output . . . . . . . . . . . 25

5 Example of Tagged Inventory . . . . . . . . . . 27

6 Example of Unobligated Inventory . . . . . . . . . 28

7 Example of Total Inventory . . . . . . . . . . . 29

8 Example of Quarterly Output . . . . . . . . . . . 31

9 Example of Assay Summary Output . . . . . . . . . 32

10 Example of Operating Parameters Summary Output . . . . 33

11 Example of Important Calculational Summary . . . . . . 34

12 Example of Assay Plot . . . . . . . . . . . . 35

13 Example Plot of ERDA Feed Requirements . . . . . . . 36

14 Example of Delay Plot . . . . . . . . . . . 37 
SCOPE

SYNERGISTIC COMPUTER OPTIMIZATION OF PLANNING

FOR ENRICHMENT

STATUS REPORT

R. C. DeLozier

D. M. Kelleher

K. E. Cross

\section{ABSTRACT}

The computer program SCOPE was developed to provide a schedule for filling orders for enriched uranium while constrained by: (1) the size and efficiency of the current and projected uranium enrichment complex; (2) the current levels of "yard inventory" of enriched uranium below 5\%; and (3) variable conditions such as projected schedule of power avallability, cascade tails assay, and the ERDA "Order Book" of firm and projected orders for enriched uranium. The program can be extended to include several more enrichment plants, such as a centrifuge plant. Output includes a detailed daily set of feed and withdrawal rates for each plant and a survey of all yard inventories at the end of each month.

The Phase I program does not contain cost tables; therefore, it cannot consider costs directly at this time. However, it does use heuristic procedures to establish preproduction schedules that will result in lower ERDA feed usage and, consequently, lower costs. The program currently relles on two files for data used in calculations. The first data set consists of all current $\mathrm{UF}_{6}$ inventories at the plants; the second data set contains the ERDA enrichment requirements. 


\section{INTRODUCTION}

The computer program package SCOPE is described briefly in this report. The program has been under development since June, 1973, by the Computer Sclences and Operations Analysis and Planning Divisions. The SCOPE program is being developed to aid in improving cascade complex production efficiency by refining scheduling procedures. Currently, the three gaseous diffusion plants operate on a short-term interactive scheduling philosophy which can be vlewed as a batch process. In other words, when enrichment orders are received, a decision is made where and when the order will be pulled. Then the required staging, power, and feed alterations at each plant are optimized using the General Productivity Code ${ }^{1}$ to process that plant's orders for the time period. It is hoped that by using SCOPE, the orders can be allocated such that the power schedules, feed alterations, and 1 ist of commitments can be consldered over an extended period of time. Furthermore, the program, given certain constraints, will evaluate the preproduction assays that should be withdrawn over the campaign. In the past, no real scheduling problems have occurred because of the relatively small demands. However, with the number of nuclear power plants increasing each year, the existing gaseous diffusion plants will be incapable of meeting orders in a very few years. Therefore, it is necessary that a comprehensive scheduling model be developed to determine the optimal or near-optimal method of operation that will fill the anticipated demands at a minimum cost. 
The computer program SCOPE was developed to provide a schedule for filling orders for enriched uranium while constrained by: (1) the size and efficiency of the current and projected uranium enrichment complex; (2) the current levels of "yard inventory" of enriched uranium below 5\%; and (3) variable conditions such as profected schedule of power avai1ability, cascade talls assay, and the ERDA "Order Book" of firm and projected orders for enriched uranium. Variables considered include reactor returns, power schedules, design capacity as a function of time, feed alterations, and list of order commitments. Output includes a detailed daily set of feed and withdrawal rates for each plant and a survey of al1 yard inventories at the end of each month.

The program currently relies on two disk files for data used in calculations. The first disk consists of all yard inventories at existing plants; the second data set contains the future ERDA enrichment requirements.

The SCOPE package should provide a computer-based tool that can compare various philosophies associated with operating several enrichment plants. The package consists of one main program and two auxiliary codes. The SCOPE system is illustrated in Figure 1. The first auxiliary program is used to generate a cylinder inventory data set, disk 1 . This information is selectively retrleved from uranium accountability data sources. The second auxiliary program is used to generate the future enrichment requirements data set, disk 2. This information is selectively retrieved from the Civilian Enrichment Requirements Program (CERP) data set. The two data sets (disks 1 and 2) can be updated as often as at 


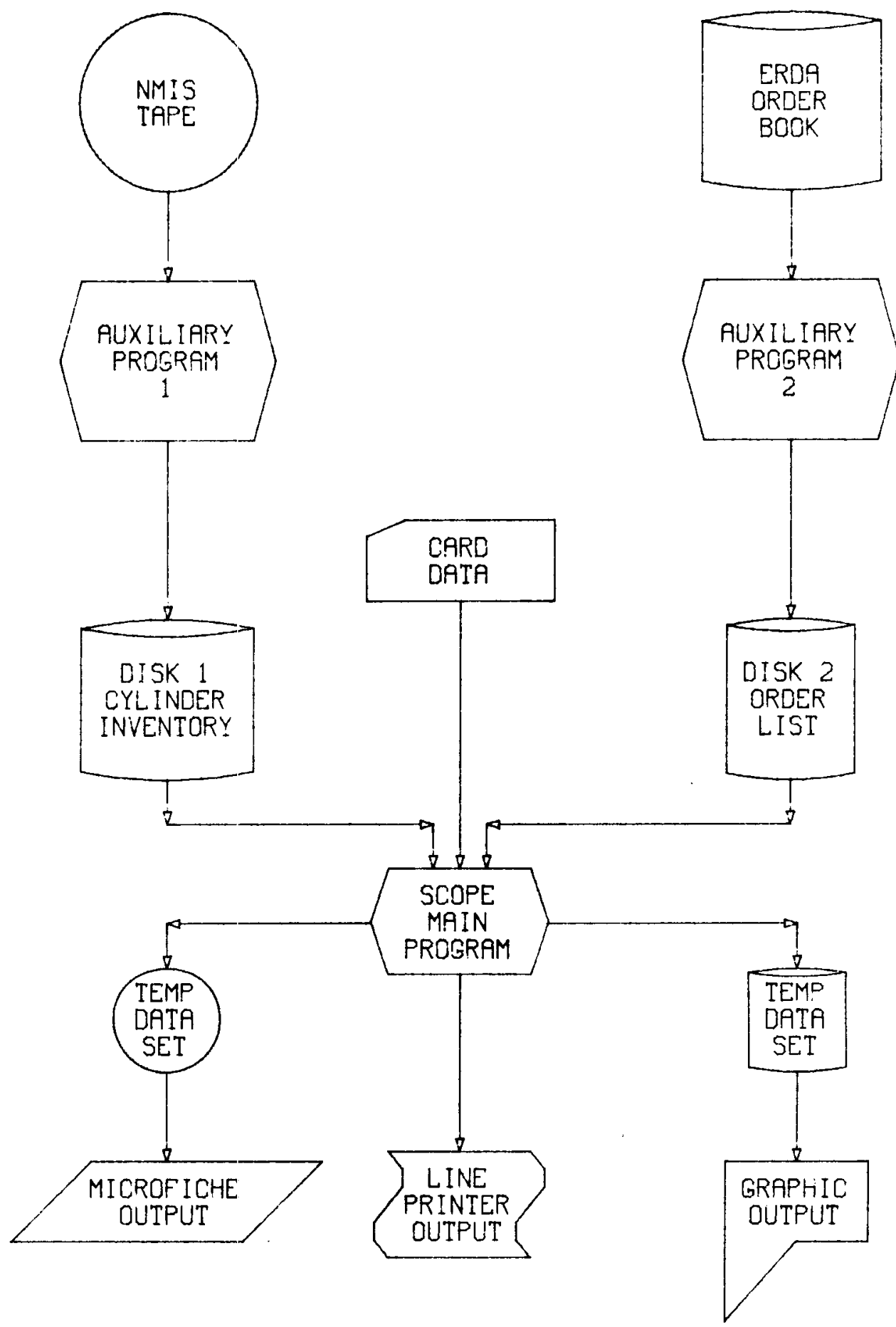

FIGURE 1

I1lustration of SCOPE Package 
one-month intervals. This data is used by the SCOPE main program to model an operating interval under an operating philosophy which is defined by the card input at execution time. 


\section{DESCRIPTION OF THE CODE}

The SCOPE programs are designed to model the interaction of several uranium enrichment plants. As indicated in Figure 1, the package consists of a main program which models the plant operations and two auxiliary programs that convert order and yard inventory files to a form acceptable to the main program.

The current program requires about 5 minutes of $\mathrm{CPU}$ time to simulate 10 years of plant operation using the infinite cylinders option. The actual clock time from run request until the time when all output is recelved is approximately 24 hours. The run produces about 30,000 1ines of print, uses $350 \mathrm{~K}$ of core, and generates $15 \mathrm{~K}$ of $\mathrm{I} / 0$. The $\mathrm{I} / 0$ requirements are used in generating microfiche output for detailed reports.

\subsection{The Main Program}

The main program is designed to model the operation of the uranium enrichment facilities on a quarter-by-quarter basis over a long period of time. The program requires as input an order 1ist, a yard inventory file, a power schedile, and operating assays. The program generates daily cascade operations reports, quarterly summary reports, and quarterly yard inventory reports.

Several options are avallable during program execution. The order list can be either read from a data file created by the order auxiliary programs or input on punched cards. The yard inventory can be handled as individual cylinders or modeled as a smaller group of very large cylinders consisting of the individual cylinders aggregated by assay 
ranges. This feature is useful for multiple runs where the time required per run is greatly reduced. The program can be set to look ahead during execution to produce orders in the cascades ahead of the quarter in which they are due and store them in the yard for later retrieval. The preproduction assay can be changed during the run based on future order expectations and the inventory.

The cascade operation shown in Figure 2 is simulated on a day-today basis. The feed and product streams shown in this figure are assigned an assay level, and the program determines the flow rates of each stream using a mathematical model. Each flow rate is calculated such that maximum and minimum flow constraints are satisfied. Therefore, there may be times when the power usage is less than that scheduled because some flow rate maximum would be exceeded under the schedule requested. The cascade mathematical model is derived from the mass, isotopic, and separative work continuities:

$$
\begin{aligned}
& \frac{\partial M}{\partial \theta}=\sum_{j=1}^{j} P_{j} \quad+\sum_{k=1}^{k} W_{k} \quad-\sum_{\ell=1}^{\ell} F_{\ell} \\
& \frac{\partial U}{\partial \theta}=\sum_{j=1}^{j}\left(P_{j} x_{P j}\right)+\sum_{k=1}^{k}\left(W_{k} x_{w k}\right)-\sum_{l=1}^{\ell}\left(F_{\ell} x_{F l}\right) \\
& S=\sum_{j=1}^{j_{\max }}\left(P_{j} V_{P j}\right)+\sum_{k=1}^{k_{\max }}\left(W V_{w k}\right)-\sum_{\ell=1}^{\ell}\left(F V_{F l}\right)
\end{aligned}
$$




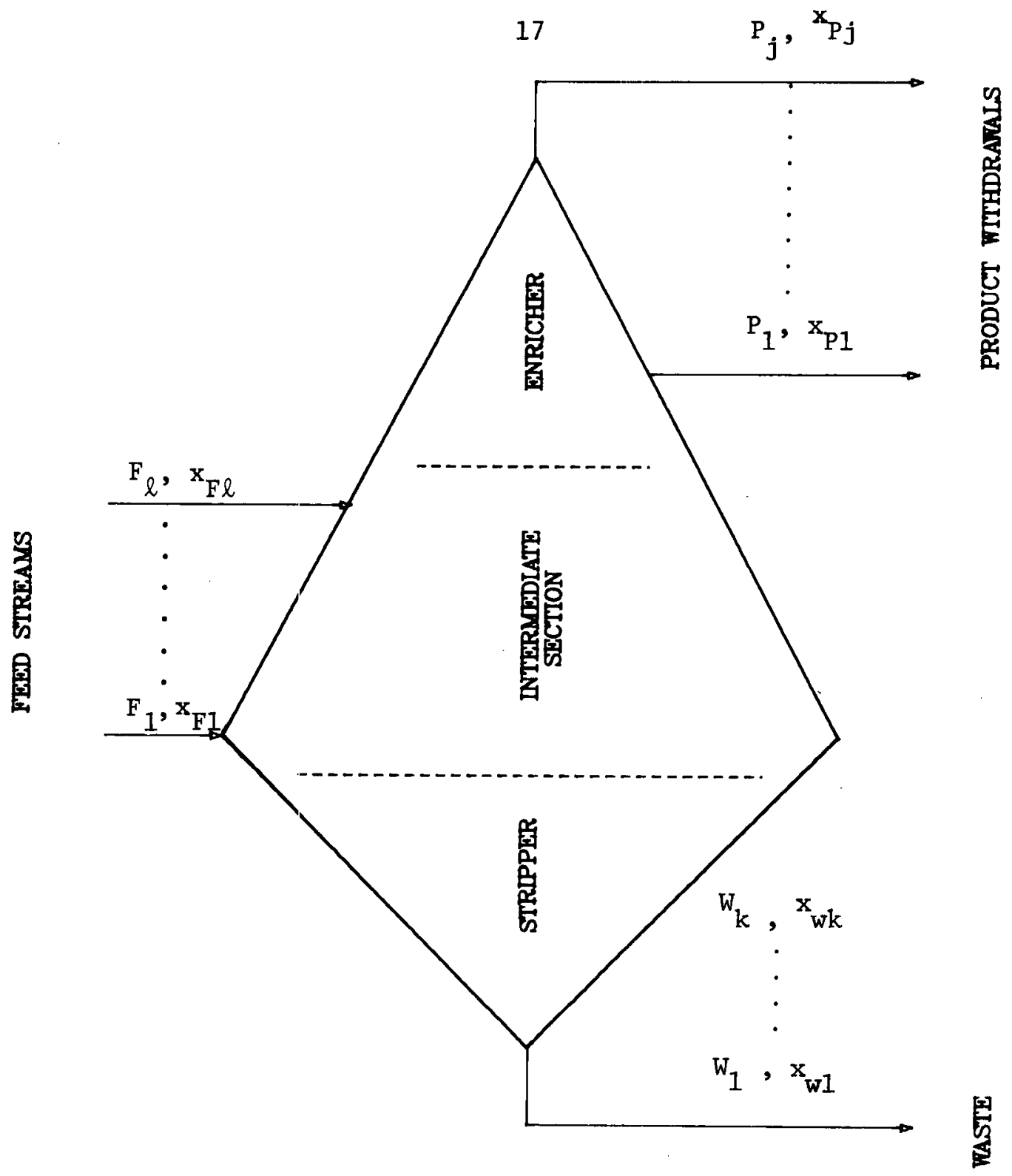

SYMBOL

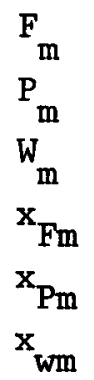

DEFINITION

Feed, Ib/day, at location m Product, $1 \mathrm{~b} /$ day, at location $\mathrm{m}$ Tails, 1b/day, at location m Feed assay of mth location. Product assay of mth location Talls assay of mth location

FIGURE 2

Cascade Mode1 
where the separative capacity,

$$
\mathrm{S}=\mathrm{SW}-\frac{\partial \mathrm{M}}{\partial \theta} \mathrm{v}_{\mathrm{a}}
$$

The value functions for product, waste, feed, and average cascade are denoted by $V_{P j}, V_{w k}, V_{F l}$, and $V_{a}$, respectively, where the assay of the appropriate stream is used in the function

$$
V=\alpha+\beta x+(2 x-1) \ln \left(\frac{x}{x-1}\right)
$$

The coefficients $\alpha$ and $\beta$ are evaluated by setting equation (5) equal to zero at the transaction tails assay and normal feed assay (.711\%).

The total mass of uranium in the plant is denoted by $M$, the total amount of the isotope U-235 is denoted by U, and the operator $\frac{\partial}{\partial \theta}$ Indicates the partial with respect to time.

For the computer model describing the Oak Ridge and Portsmouth plants, one feed stream at each plant is assigned to use Paducah product, and one stream is assigned to the preproduction assay. The orders are received as a list each quarter and can be produced at any of the plants if within certain assay restrictions. They are allocated to the three plants based on the available separative work at each plant.

The separative work available at each plant denoted as SW in equation (4) is determined from the power schedule read in and the enrichment complex physical model stored as power versus separative work tables within the program. An example plot of these tables for ORGDP is shown in Figure 3. The program reads the power avallable from the input data and finds the separative work available by interpolating between entries on the table for that fiscal year. There is a different table 


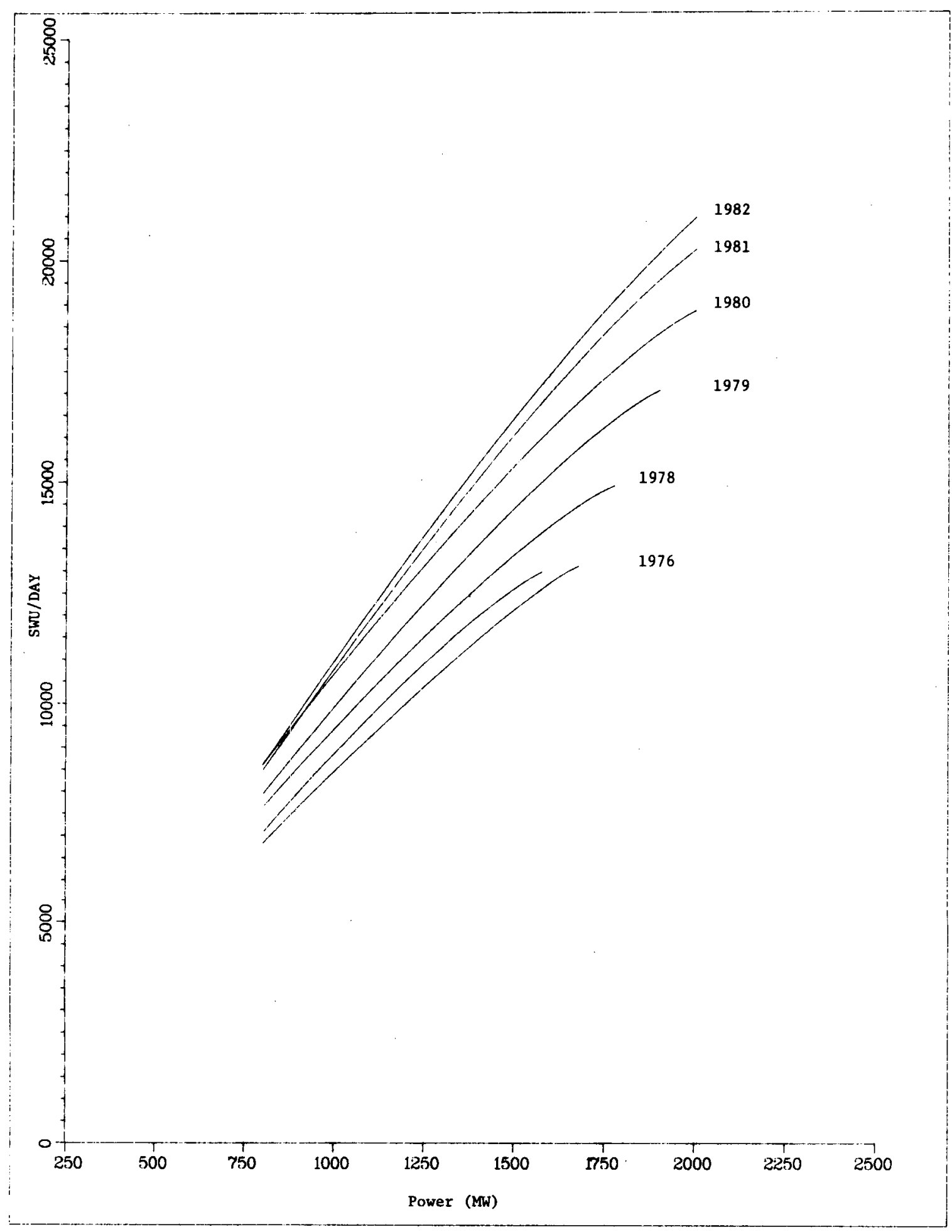

FIGURE 3

Example of Separative Capacity Versus Power for Oak Ridge Gaseous Diffusion Plant 
for each flscal year from 1977 to 1987, and all subsequent years use the 1987 table. The program can receive separative work data along with the power data and use those values for separative work rather than the tables.

\subsection{The Order Auxiliary Program}

The order list can be entered manually into the program as card Input or can be drawn from the Civilian Enrichment Requirements Program (CERP) files as indicated in Figure 1. A set of auxiliary programs reads, manipulates, and writes out the order file on another file. The program can pass on or reject orders based on the type of order. The program can also group the orders by assay range.

\subsection{The Inventory Auxiliary Program}

The uranium inventory is taken from the computerized uranium accountability files managed by the three plants. As shown in Figure 1, an auxiliary program searches the file and retrieves records on the cylinders of $\mathrm{UF}_{6}$. The cylinders are then classified according to type. The file created by this operation is then read directly into SCOPE and provides an initial yard inventory for each study. 


\section{HEURISTIC METHODS}

The original operating schedules for SCOPE were determined using dally scheduling techniques which satisfled feed and power restriction of the plants while attempting to meet commitments for product. Many operating parameters such as preproduction assay were chosen as input data before a run was made. Many runs with different input data were made to find more desirable operating schedules. This approach required considerable machine time for multiple runs and a long delay in determining what cases to try. A desirable extension to a model like SCOPE is to assign values to parameters and then to automate the manipulation of input variables in a manner that yields an optimum solution.

With the many goals in the operation of an enrichment plant such as low feed requirements, minimum order delays, and smooth feed and withdrawal schedules, an optimum solution is at best difficult to even define. Also, with the many variables that could be changed and the infinite operations schedules possible, it may be impractical to find an optimum schedule. However, decision rules and calculations can be made to determine how to choose values of variables such that a very good, if not optimal, solution is obtained. A.heuristic approach can often yield a near-optimal solution with a relatively small investment in increased running time for a model.

The Initial variables to be manipulated automatically by the model are the yearly preproduction assays. The choice of a preproduction assay for each quarter is made by the model after a production schedule for all previous quarters has been determined. The available data such 
as stockpiles and future demands is evaluated and a preproduction assay chosen for the next quarter. This procedure is repeated for each quarter of a campalgn.

The first heuristic program looked ahead and chose a preproduction assay for which demand exceeded the current stockpile by the greatest amount. This procedure is a yard leveling scheme which attempts to avoid delaying orders and also yields great flexibility in case the order schedule is changed.

In addition to filling orders without delays, using less ERDA feed is a desirable goal which will reduce costs. In order to reduce feed usage, it is desirable to preproduce high assay material first. This is accomplished by modifying the heuristic calculations to continue producing the highest assay allowable until the stockpile of that material meets all future demands. Although this procedure uses less feed early, it does not have the ability to meet changes in orders as well as the yard leveling scheme. Other decision rules can be incorporated easily to consider other desirable operations goals. 


\section{OUTPUT REPORTS}

Three types of reports are generated by the main program. The detail reports contain all of the information generated by the program. They are usually written on microfiche to save paper. Summary reports are generated for each quarter and are printed on paper. A temporary data set is written on disk file and analyzed by another program that generates graphical output of summary information presented in the summary reports.

The detail reports show all of the information generated by the main program. The three types of information shown are input data, intermediate results, and final results. The input data shown includes the flag options, run dates, and initial inventory. The order lists and operating assays for each quarter are also shown. The intermediate results shown include the list of orders sent to the cascade and the daily balances made by the cascade model. An example of daily balances made by the cascade is shown in Figure 4. The final results shown include orders delayed and an ending inventory. The ending inventory is separated into three groups of material. The first group, shown in Figure 5, is the orders produced that quarter to fill a total short-range demand. These orders are stored in the yard for later retrieval and are called "tagged" orders. The second group, shown in Figure 6, is the rest of the inventory. The third group, shown in Figure 7, represents the total inventory and is the sum of the first two groups.

The summary reports show a page of operating information and the ending inventory for each quarter. The operating information shown includes the operating assays, plant power and separative work, orders 
UPERATING REPURT
FUK MONTH 1/ 77

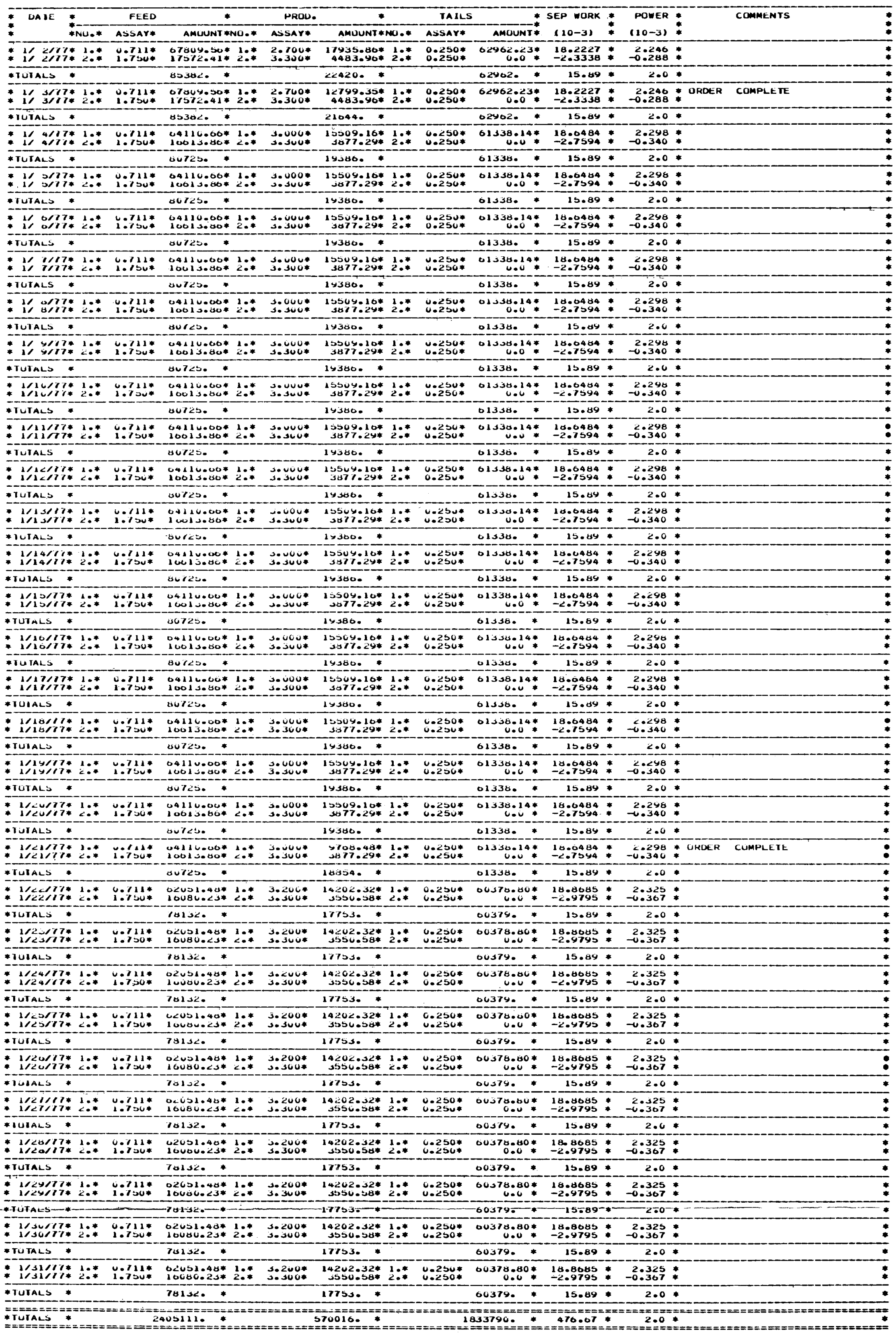

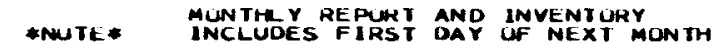

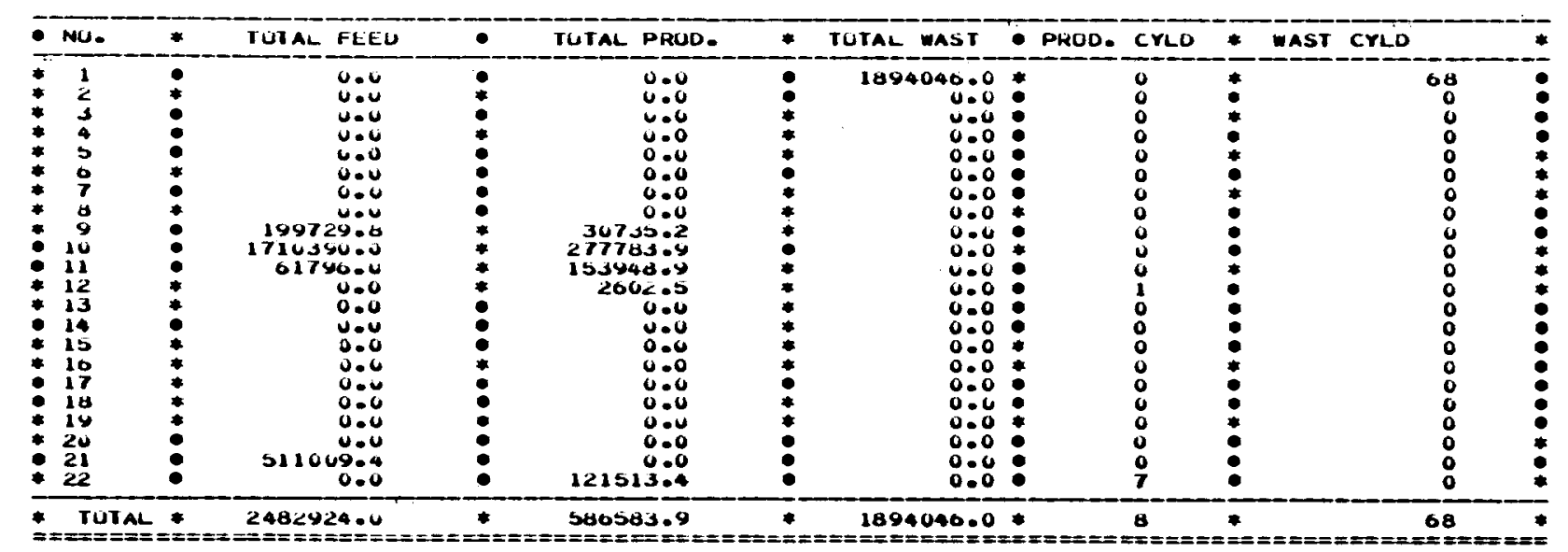




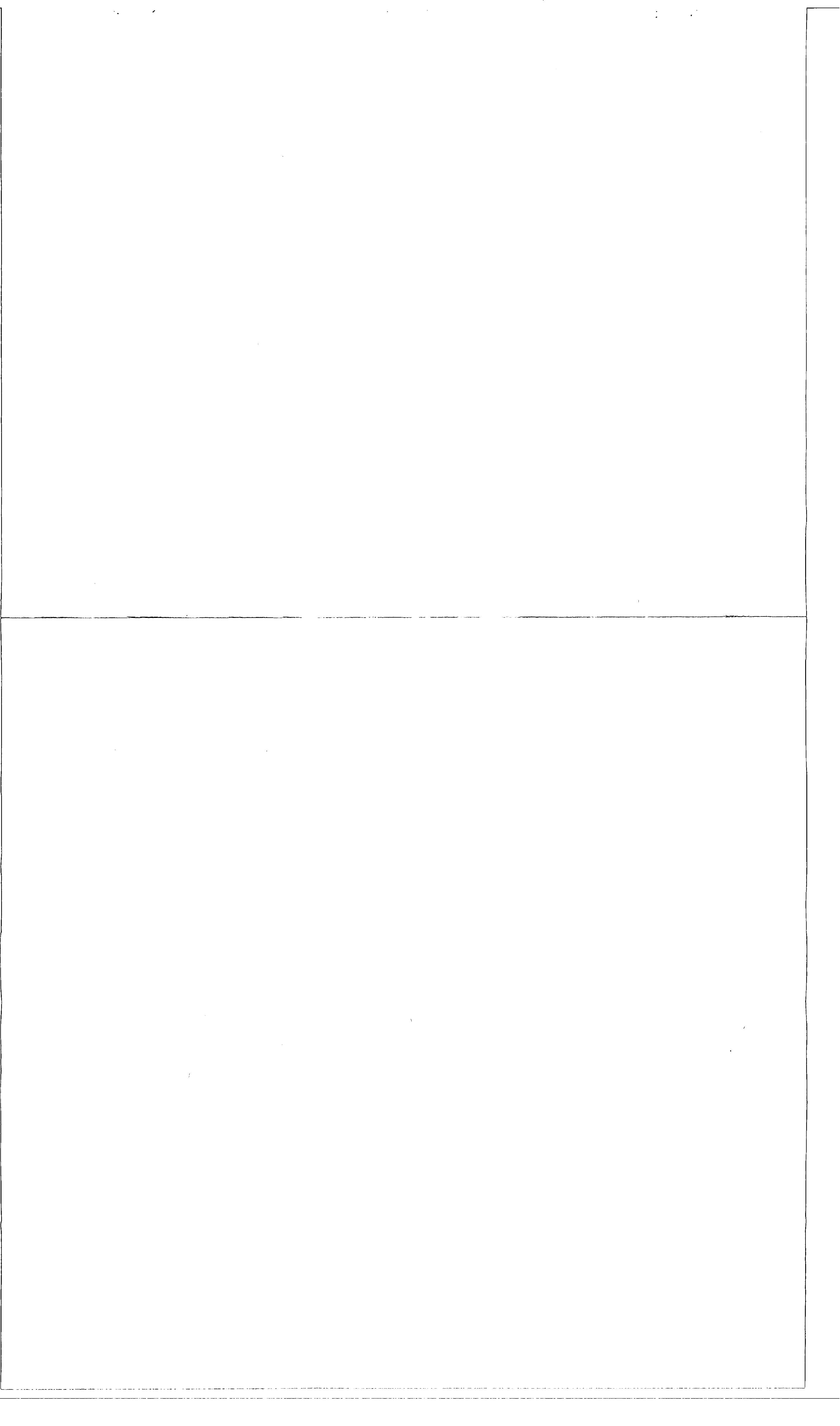


WAK RILGE IAGGLU CYLINUEK INVENTORY

\begin{tabular}{|c|c|c|c|c|c|c|c|c|c|c|}
\hline A SSAY & $\begin{array}{l}14-1 \text { in } \\
\text { ship. }\end{array}$ & $\begin{array}{l}\text { CYLINOEKS } \\
\text { UNSHIP. IMIN }\end{array}$ & $\checkmark$ WALL & SHip. & $\begin{array}{l}\text { CYLINDE RS } \\
\text { UNSHIP. DHIN }\end{array}$ & WALL & SHIS- & $\begin{array}{l}\text { ON CYLINUERS } \\
\text { UNSHIP. IHIN }\end{array}$ & EALL & $\begin{array}{l}\text { AMOUNT } \\
\text { (MIU) }\end{array}$ \\
\hline 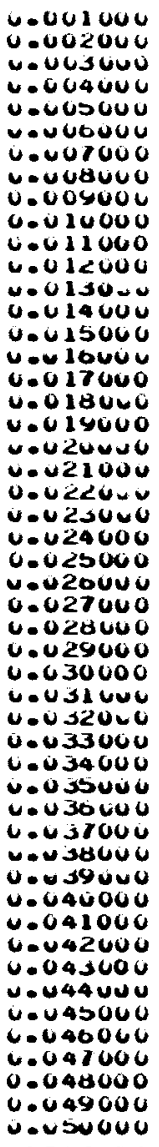 & 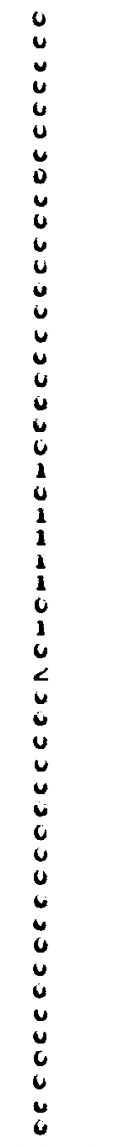 & $\begin{array}{l}u \\
u \\
u \\
u \\
u \\
u \\
u \\
u \\
u \\
u \\
u \\
u \\
u \\
u \\
u \\
u \\
u \\
u \\
u \\
u \\
z \\
u \\
u \\
u \\
u \\
u \\
u \\
u \\
u \\
u \\
u\end{array}$ & 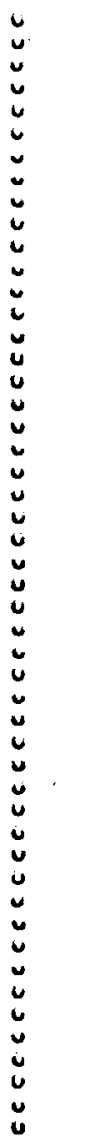 & 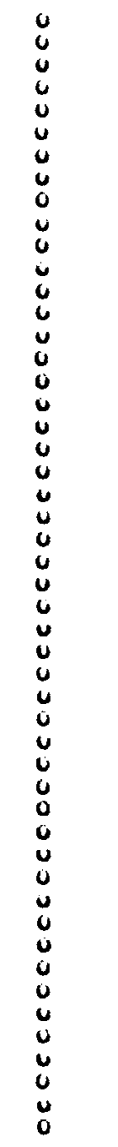 & 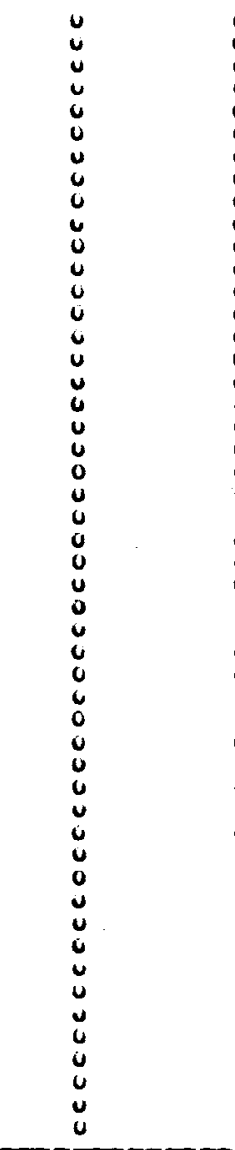 & 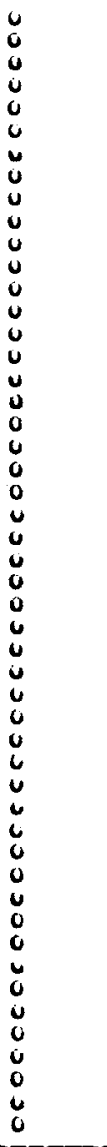 & $\begin{array}{l}0 \\
0 \\
0 \\
0 \\
0 \\
0 \\
0 \\
0 \\
0 \\
0 \\
0 \\
0 \\
0 \\
0 \\
0 \\
0 \\
0 \\
0 \\
0 \\
0 \\
0 \\
0 \\
0 \\
0 \\
0 \\
0 \\
0 \\
0 \\
j \\
0 \\
0 \\
u \\
0 \\
0 \\
0 \\
0 \\
0 \\
0 \\
0 \\
0 \\
0\end{array}$ & $\begin{array}{l}0 \\
0 \\
0 \\
0 \\
0 \\
0 \\
0 \\
0 \\
0 \\
0 \\
0 \\
0 \\
0 \\
0 \\
0 \\
0 \\
0 \\
0 \\
0 \\
0 \\
0 \\
0 \\
0 \\
0 \\
0 \\
0 \\
0 \\
0 \\
0 \\
0 \\
0 \\
0 \\
0 \\
0 \\
0 \\
0 \\
0 \\
0 \\
0 \\
0 \\
0 \\
0 \\
0 \\
0\end{array}$ & $\begin{array}{l}0 \\
0 \\
0 \\
0 \\
0 \\
0 \\
0 \\
0 \\
0 \\
0 \\
0 \\
0 \\
0 \\
0 \\
0 \\
0 \\
0 \\
0 \\
0 \\
0 \\
0 \\
0 \\
0 \\
0 \\
0 \\
0 \\
0 \\
0 \\
0 \\
0 \\
0 \\
0 \\
0 \\
0 \\
0 \\
0 \\
0 \\
0 \\
0 \\
0 \\
0 \\
0 \\
0 \\
0 \\
0 \\
0 \\
0\end{array}$ & 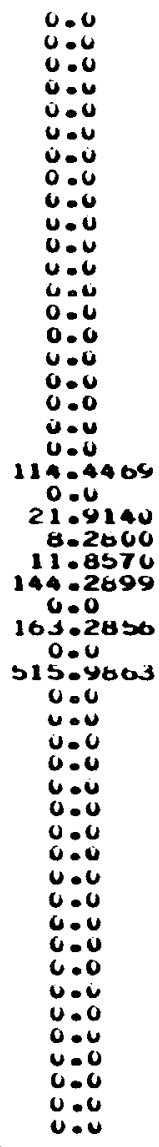 \\
\hline
\end{tabular}

Example of Tagged Inventory 


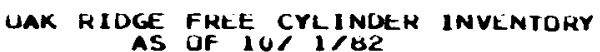

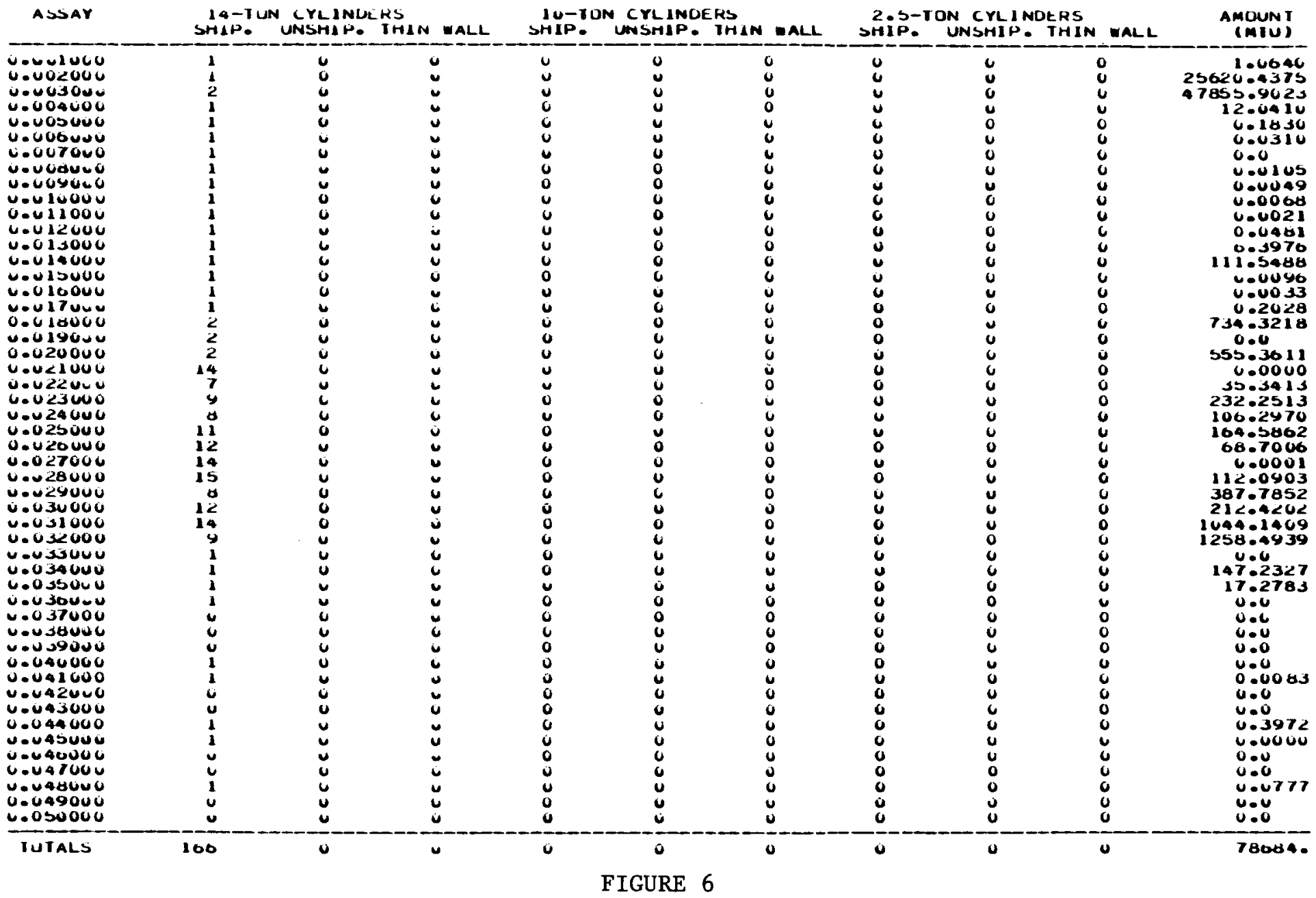

Example of Unobligated Inventory 
UAK RIDGE TOTAL CYLINUER INVENTORY

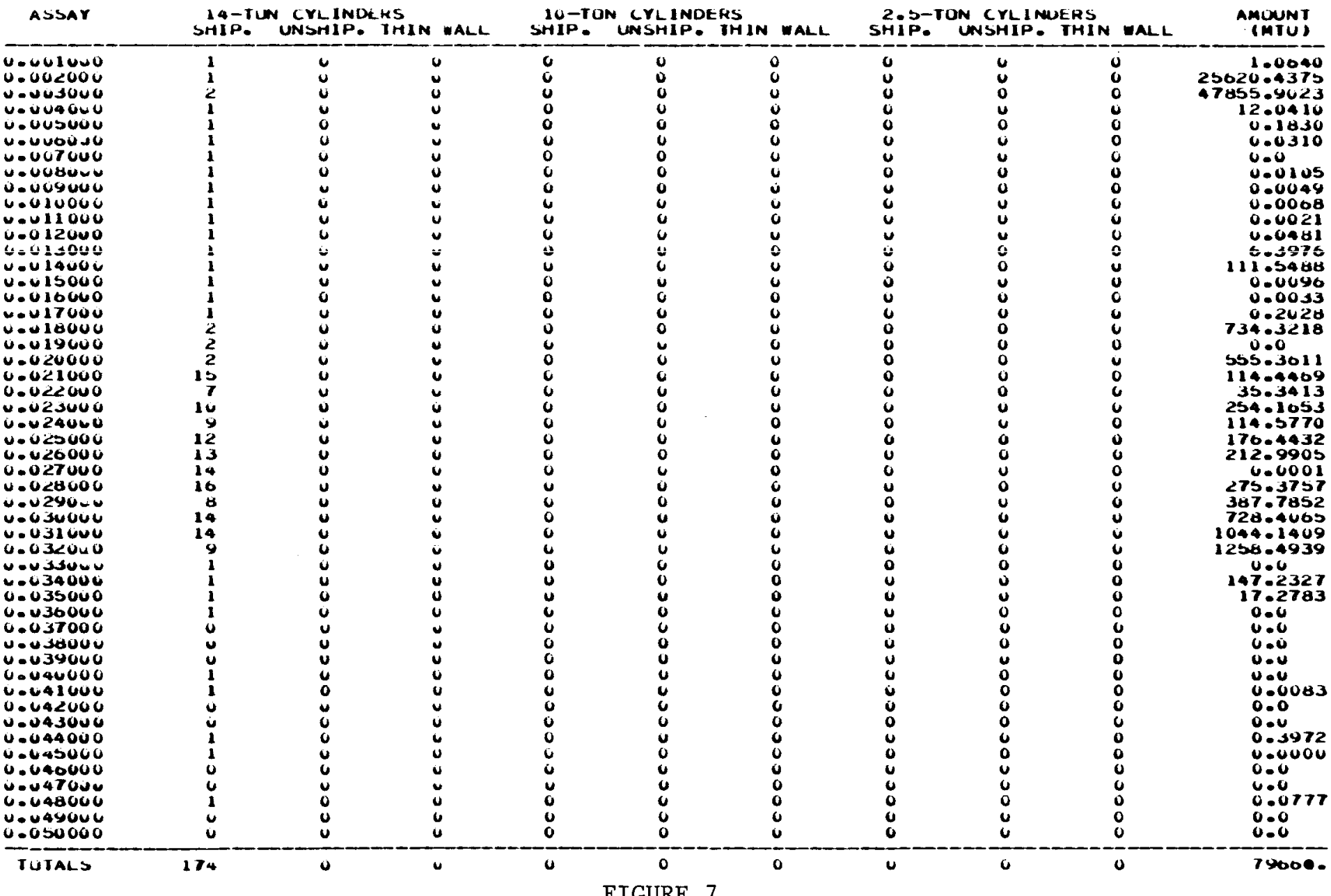

Example of Total Inventory 
recelved and delayed, uranium normal feed requirements, and an inventory summary. The ending information shown is the same as the detail report described above. Examples of the ending inventory reports are shown in Figures 5, 6, and 7; and an example of an operating information report is shown in Figure 8.

The tables shown in Figures 9, 10, and 11 are generated by another program that reads a temporary data set created by the main program. The information presented is the same as that shown on the operating Information summary report. The tables are organized on a quarter-byquarter basis. The temporary data set can also be read and analyzed by a plotting program. Figures 12,13 , and 14 are examples of plots that can be produced from the information on the data set. In these last three example plots, the type of lettering was varied to illustrate some of the options available using the DISSPLA software. 2 
SUMMART REFURT FUR PERIUU NUMGER 23

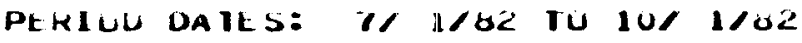

ASSAY VALUES:

HRE-PRUUUCTION:

PADUCAM PRUUUCT:

NUKMAL FEED:

CASCADE TAILS:

TRANSACIION TALLS:

$-03400$

- 01900

- UC711

- 00235

- vo 200

DUWKR ANU SEPAKATIVL WUKK AVAILASLE:

UAK RILGE HUWER (MW):

LAK RIUGE SEPAKAIIVE WURK:

PaLUCAaH FuWE (MW):

PALULAH SEPAKATIVE WOKK:

PURTSMUUTH PUWTK (MW):

PURI SMUUIH SEPARATIVE WURK:

1740. 18837. 2572 . $277<4$. 2260 . 23008.

WHUER INF URMAT IUN:

NUMBER RECE I VEO:

NUMBER DELLAYEL:

NUMUER OF UELAYS TU LAIE:

SLPAKATIVE WORK VALUE UF OLLAYEU URUERS (*):

CUMEINEU PLANT UKANIUM NUKMAL FEEU RLGUIREMENTS (MTU):

THIS HERIUO:

TUTAL URANIUM FEO TL CASCAUESE

TUTAL URANIUM RECEIVEO FRUM CUSTUMKRS:

9730.

IUTAL TRUA-UWNED URANIUM REUUIREL:

SINCL START UF RUN:

TUTAL uKaniuM fEO TO CAScades:

TUTAL URANIUM RECEIVED FROM CUSTOMEKS:

193381.

IUTAL EHUA-UUNEU UKANIUM REUUIREO:

CUMEINE D PLANT STUCKPILE:

ME TRIC TUNS URANIUM:

SEPARATIVE WORK UNITS (*):

17808.

AVERAGE ASSAY:

* in thuusanios uf KG-simu. based un separailve wurk values ut ZEKU FUR ASSAYS OF .0O711 ANO . UOZOO.

\section{FIGURE 8}

Example of Quarterly Output 


\begin{tabular}{|c|c|c|c|c|c|c|c|c|c|c|}
\hline 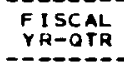 & $\begin{array}{l}\text { CALENADAI } \\
\text { START }\end{array}$ & $\begin{array}{c}\text { DATES } \\
\text { END }\end{array}$ & $\begin{array}{l}\text { OAK } \\
\text { PCWER }\end{array}$ & $\begin{array}{l}\text { UGE } \\
\text { SEP }\end{array}$ & $\begin{array}{r}P A D \\
\text { POWER }\end{array}$ & $\begin{array}{l}\text { CAM W WK } \\
\text { SEP WK }\end{array}$ & POWE & SEP & & se. \\
\hline $\begin{array}{l}1977-2 \\
1977-3 \\
1977-4 \\
-197\end{array}$ & $\begin{array}{l}1 / 11>77 \\
4 \prime 1177 \\
31\end{array}$ & $\begin{array}{r}4 \\
701978 \\
1087\end{array}$ & $\begin{array}{l}900: \\
612: \\
990:\end{array}$ & $\begin{array}{l}7983: \\
5275: \\
9341:\end{array}$ & $\begin{array}{l}1320: \\
948: \\
13800\end{array}$ & $\begin{array}{l}12853 \\
9836 \\
14530\end{array}$ & $\begin{array}{l}1194 \\
1194: \\
11940\end{array}$ & $\begin{array}{llll}1 & 1 & 0 & 13 \\
1 & 1 & 0 & 1 \\
1 & 1 & 6 & 13\end{array}$ & $\begin{array}{l}3414: \\
2754: \\
3564:\end{array}$ & $\begin{array}{l}31855 \\
26124: \\
35517:\end{array}$ \\
\hline 1977 & $1 / 1 / 77$ & $10 / 1 / 77$ & & $225 \times 9$. & & 37229. & & 33668 & & 93496 \\
\hline $\begin{array}{l}1978-1 \\
1978-2 \\
1978-3 \\
1978-4\end{array}$ & $\begin{array}{l}101 \\
1 / 77 \\
41<78 \\
71,1 / 78\end{array}$ & $\begin{array}{r}1 / 1 / 78 \\
41,1 / 78 \\
70 \\
101 / 78\end{array}$ & $\begin{array}{l}795: \\
789: \\
615: \\
921:\end{array}$ & $\begin{array}{l}7589: \\
7533: \\
5893: \\
9148:\end{array}$ & $\begin{array}{l}1380 . \\
1386: \\
1245: \\
1494 .\end{array}$ & $\begin{array}{l}14534: \\
14534: \\
14534: \\
17378 .\end{array}$ & $\begin{array}{l}11940 \\
11940 \\
11940 \\
1194:\end{array}$ & $\begin{array}{l}11642 \\
11642: \\
11642: \\
13037:\end{array}$ & $\begin{array}{l}3369: \\
3369: \\
3054: \\
3609:\end{array}$ & $\begin{array}{l}33765: \\
33709: \\
32069: \\
38563:\end{array}$ \\
\hline 1978 & 1011177 & $10<1 / 78$ & & 30163. & & 60990. & & 45963. & & 138106 \\
\hline $\begin{array}{l}1979-1 \\
1979-2 \\
1979-3 \\
1979-4\end{array}$ & $\begin{array}{r}101 / 78 \\
1111799 \\
311,79\end{array}$ & 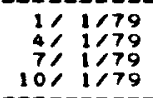 & $\begin{array}{l}921: \\
942: \\
942 \\
939:\end{array}$ & $\begin{array}{r}9140 . \\
9356: \\
93560 \\
10061:\end{array}$ & $\begin{array}{l}1494 \\
\text { 1545: } \\
\text { 1545: } \\
1572:\end{array}$ & $\begin{array}{l}173780 \\
17378: \\
17378: \\
19036:\end{array}$ & $\begin{array}{ll}1 & 194 \\
1 & 194 \\
1 & 194 \\
1 & 194\end{array}$ & $\begin{array}{l}12037 \\
122037: \\
122037: \\
12505:\end{array}$ & $\begin{array}{l}3609: \\
3681: \\
3681: \\
3705\end{array}$ & $\begin{array}{l}38563: \\
38771: \\
38771: \\
41597:\end{array}$ \\
\hline 1979 & $10 / 1 / 78$ & $10 / 1 / 79$ & & 37921 . & & 71170 . & & 48511. & & 157702 \\
\hline $\begin{array}{l}1980-1 \\
1980-2 \\
1980-3 \\
1980-4\end{array}$ & $\begin{array}{l}101<79 \\
111<80 \\
411<80 \\
\$ 11800\end{array}$ & $\begin{array}{r}111<80 \\
71<80 \\
1011<80\end{array}$ & $\begin{array}{r}972: \\
972: \\
984: \\
1041:\end{array}$ & $\begin{array}{l}10398: \\
10398: \\
10521: \\
11250:\end{array}$ & $\begin{array}{l}1611 . \\
1611: \\
1629: \\
1572:\end{array}$ & $\begin{array}{l}19036 . \\
19360 \\
19036: \\
20140 .\end{array}$ & $\begin{array}{l}1194 . \\
1194: \\
11940 \\
1194 .\end{array}$ & $\begin{array}{l}125000 \\
12509: \\
12500: \\
12752:\end{array}$ & $\begin{array}{l}3777 \\
3777: \\
3807 \\
3807:\end{array}$ & $\begin{array}{l}41934: \\
41934 \\
42657 \\
441420\end{array}$ \\
\hline 1980 & $10 / 1 / 79$ & $10 / 1 / 30$ & & 42567 & & 77248 . & & 50252. & & 170067 \\
\hline $\begin{array}{l}1981-1 \\
1981-2 \\
1981-3 \\
1981-4\end{array}$ & 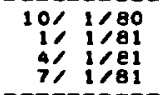 & 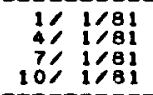 & & $\begin{array}{l}112500 \\
111250: \\
111250 \\
117930\end{array}$ & $\begin{array}{l}1572 . \\
1572: \\
1572 . \\
1536 .\end{array}$ & $\begin{array}{l}201400 \\
20140: \\
20140: \\
21159:\end{array}$ & & $\begin{array}{l}12752: \\
112752: \\
12752: \\
15091:\end{array}$ & $\begin{array}{l}3807 \\
3807: \\
3807: \\
3801:\end{array}$ & $\begin{array}{l}441420 \\
46142: \\
44142 \\
49043:\end{array}$ \\
\hline 1981 & $10<1<80$ & $1011 / 01$ & & 45543. & & 81579 & & 54347 & & 181469 \\
\hline $\begin{array}{l}1982-1 \\
1982-2 \\
1982-3 \\
1982-4\end{array}$ & $\begin{array}{l}1 c / 1<81 \\
1 / 1<82 \\
4 / 1>82 \\
7 / 1 / 82\end{array}$ & $\begin{array}{r}11 \\
41 / 82 \\
7 \prime 1 / 82 \\
10,1 / 82 \\
1082\end{array}$ & $\begin{array}{l}1071: \\
1071: \\
1071: \\
1071:\end{array}$ & $\begin{array}{l}11793: \\
11793: \\
11793: \\
117930\end{array}$ & $\begin{array}{l}15360 \\
1536 \\
1536 \\
1536\end{array}$ & $\begin{array}{l}21159: \\
21159: \\
21159: \\
21159:\end{array}$ & $\begin{array}{l}11940 \\
1194: \\
11940 \\
1194:\end{array}$ & $\begin{array}{l}16091 \\
15091: \\
16091: \\
15091:\end{array}$ & $\begin{array}{l}3801 \\
3801: \\
3801: \\
3801:\end{array}$ & $\begin{array}{l}49043 \\
490430 \\
49043 \\
49043\end{array}$ \\
\hline 1982 & $10 / 1181$ & $10 / 1 / 82$ & & 47172. & & 84636 & & 64364 & & 196172. \\
\hline $\begin{array}{r}1983-1 \\
1983-2 \\
1983-3 \\
1983-4\end{array}$ & $\begin{array}{r}10 / 1 / 82 \\
1 / 1 / 83 \\
11 / 1 / 83 \\
71,183\end{array}$ & 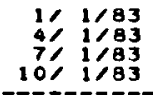 & $\begin{array}{l}1071: \\
1071: \\
1071: \\
1065:\end{array}$ & $\begin{array}{l}11793: \\
11793: \\
11793: \\
11724:\end{array}$ & $\begin{array}{l}1536 \\
1536 \\
1536 \\
1542\end{array}$ & $\begin{array}{l}21159: \\
21159: \\
21159: \\
21159:\end{array}$ & $\begin{array}{l}11940 \\
1194: \\
1194: \\
1194:\end{array}$ & $\begin{array}{l}16091: \\
15091: \\
16091: \\
16091:\end{array}$ & $\begin{array}{l}3801: \\
3801: \\
3801: \\
3801:\end{array}$ & $\begin{array}{l}490430 \\
49043: \\
49043: \\
48974:\end{array}$ \\
\hline 1983 & $1 \mathrm{c} / 1 / 82$ & $10 / 1 / 83$ & & 47103. & & 84635. & & 64364. & & 196103. \\
\hline $\begin{array}{l}1984-1 \\
1984-2 \\
1984-3 \\
1984-4\end{array}$ & $\begin{array}{r}10 / 1 / 83 \\
1 / 1 / 84 \\
411 / 84 \\
71,84\end{array}$ & 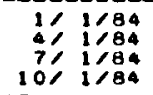 & 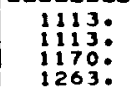 & $\begin{array}{l}12275 . \\
\text { 12275: } \\
12918: \\
13950 .\end{array}$ & $\begin{array}{l}1617.0 \\
1617 \\
1717 \\
1824:\end{array}$ & $\begin{array}{l}21159 . \\
21159 . \\
211159 \\
21159\end{array}$ & $\begin{array}{l}119 \\
119 \\
119\end{array}$ & $\begin{array}{l}15091: \\
15091: \\
15091: \\
15091:\end{array}$ & $\begin{array}{l}3924: \\
3924: \\
4077 \\
4281:\end{array}$ & $\begin{array}{l}49525: \\
49525: \\
50168: \\
51200:\end{array}$ \\
\hline 1984 & $10 / 1 / 83$ & $10 / 1 / 89$ & & 51418 & & 84636 & & $64364:$ & & 200418 \\
\hline $\begin{array}{l}1985-1 \\
1985-2 \\
1985-3\end{array}$ & $\begin{array}{c}10 / 1 / 84 \\
1 / 1 \\
4 /, 1 / 85\end{array}$ & $\begin{array}{l}1 \geq 1 / 85 \\
4 \geq 1 / 85 \\
71 / 85\end{array}$ & $\begin{array}{l}1263 \\
1263: \\
1263:\end{array}$ & $\begin{array}{l}13950: \\
13950: \\
13950:\end{array}$ & $\begin{array}{l}1824: \\
1824: \\
1824:\end{array}$ & $\begin{array}{r}21159 \\
21159: \\
21159 \\
-\end{array}$ & $\begin{array}{l}11940 \\
1194: \\
1194:\end{array}$ & $\begin{array}{l}15091: \\
15091: \\
15091:\end{array}$ & $\begin{array}{l}4281: \\
4281: \\
4281:\end{array}$ & $\begin{array}{l}51200 \\
51200 \\
51200\end{array}$ \\
\hline 1985 & $1011 / 84$ & $7 / 1 / 85$ & & 41850. & & 63477 & & $\begin{array}{r}49273 \\
- \\
-\end{array}$ & & $15360 \mathrm{c}$. \\
\hline TOTAL & $1 / 1 \geq 7$ & $711 / 8$ & & 5336 & & 645591. & & 475200 & & 11487133. \\
\hline
\end{tabular}

FIGURE 9

Example of Assay Summary Output 
A S S A Y S

\begin{tabular}{|c|c|c|c|c|c|c|c|c|}
\hline $\begin{array}{l}\text { FISCAL } \\
\text { YR-UTR }\end{array}$ & $\begin{array}{l}\text { CAL } \\
\text { STAl }\end{array}$ & $\begin{array}{l}\text { LENDAF } \\
\text { RT }\end{array}$ & $\begin{array}{r}\text { DATES } \\
\text { END }\end{array}$ & $\begin{array}{l}\text { PRE-PRO- } \\
\text { DUCTION }\end{array}$ & $\begin{array}{l}\text { PADUCAH } \\
\text { PRODUCT }\end{array}$ & $\begin{array}{l}\text { NORMAL } \\
\text { FEED }\end{array}$ & $\begin{array}{l}\text { CASCADE } \\
\text { TAILS }\end{array}$ & $\begin{array}{l}\text { TZANS. } \\
\text { TAILS }\end{array}$ \\
\hline $\begin{array}{l}1977-2 \\
1977-3 \\
1977-4\end{array}$ & $\begin{array}{l}1 \% \\
4 \%\end{array}$ & $\begin{array}{l}1 / 77 \\
1 / 77 \\
1 / 77\end{array}$ & $\begin{array}{r}4 / 1 / 77 \\
7 / 1177 \\
10 / 1<77\end{array}$ & $\begin{array}{l}.03000 \\
.03000 \\
.03000\end{array}$ & $\begin{array}{r}01750 \\
.01750 \\
.01750\end{array}$ & $\begin{array}{l}.00711 \\
.00711 \\
.00711\end{array}$ & $\begin{array}{l}.00250 \\
.00250 \\
00250\end{array}$ & $\begin{array}{l}.00203 \\
.00200 \\
.00205\end{array}$ \\
\hline $\begin{array}{l}1978-1 \\
1978-2 \\
1978-3 \\
1978-4\end{array}$ & $\begin{array}{l}10 / \\
1 / \\
4 \% \\
7 /\end{array}$ & $\begin{array}{l}1 / 77 \\
1 / 78 \\
1 / 78 \\
1 / 78\end{array}$ & $\begin{array}{l}1 / 1 / 78 \\
4 / 1 / 78 \\
7 / 1 / 78 \\
10,1 / 78\end{array}$ & $\begin{array}{l}.03000 \\
.03000 \\
.03000 \\
.03000\end{array}$ & $\begin{array}{l}.02000 \\
.02000 \\
.02000 \\
.02000\end{array}$ & $\begin{array}{l}.00711 \\
.00711 \\
.00711 \\
.00711\end{array}$ & $\begin{array}{l}.02250 \\
.00250 \\
00250 \\
000235 \\
.00235\end{array}$ & $\begin{array}{l}.00200 \\
.00205 \\
.00200 \\
.0020 \\
.00200\end{array}$ \\
\hline $\begin{array}{l}1979-1 \\
1979-2 \\
1979-3 \\
1979-4\end{array}$ & $\begin{array}{l}10 \% \\
1 \% \\
4 \% \\
7 \%\end{array}$ & $\begin{array}{l}1>78 \\
1<79 \\
1<79 \\
1<79\end{array}$ & $\begin{array}{r}1 / 1 / 79 \\
4 ; 1 ; 79 \\
7 / 1 / 79 \\
10,1 / 79\end{array}$ & $\begin{array}{l}.03000 \\
.03000 \\
.03000 \\
.03000\end{array}$ & $\begin{array}{l}.02000 \\
.02000 \\
.02000 \\
.02000\end{array}$ & $\begin{array}{l}.00711 \\
.00711 \\
.00711 \\
.00711\end{array}$ & $\begin{array}{l}.00235 \\
.002335 \\
.00235 \\
.00235\end{array}$ & $\begin{array}{l}.00200 \\
-00200 \\
-002020 \\
.00200 \\
.00200\end{array}$ \\
\hline $\begin{array}{l}1980-1 \\
1980-2 \\
1980-3 \\
1980-4\end{array}$ & $\begin{array}{l}10 \% \\
1 \% \\
4 \%\end{array}$ & $\begin{array}{l}1<79 \\
1<80 \\
1<80 \\
1 / 80\end{array}$ & $\begin{array}{l}1 / 1 / 80 \\
4 / 1 / 80 \\
7 / 1 / 80 \\
10 / 1 / 80\end{array}$ & $\begin{array}{l}.03000 \\
.03000 \\
.03000 \\
.03000\end{array}$ & $\begin{array}{r}.02000 \\
.01900 \\
.01900 \\
.0190 \\
.01900\end{array}$ & $\begin{array}{l}.00711 \\
.00711 \\
.00711 \\
.00711\end{array}$ & $\begin{array}{l}.00235 \\
.00235 \\
.00235 \\
.00235\end{array}$ & $\begin{array}{l}.00200 \\
.00205 \\
.00205 \\
.00200\end{array}$ \\
\hline $\begin{array}{l}1981-1 \\
1981-2 \\
1981-3 \\
1981-4\end{array}$ & $\begin{array}{l}10 / \\
11 \\
4 \prime \\
71\end{array}$ & $\begin{array}{l}1<80 \\
1<81 \\
1<81 \\
1<81\end{array}$ & $\begin{array}{l}1 / 1 / 81 \\
4 / 1 / 81 \\
7 / 1 / 81 \\
10 / 1 / 81\end{array}$ & $\begin{array}{l}.03000 \\
.03000 \\
.03000 \\
.03000\end{array}$ & $\begin{array}{r}.01900 \\
.01900 \\
.01900 \\
.01900\end{array}$ & $\begin{array}{l}.00711 \\
.00711 \\
.00711 \\
.00711\end{array}$ & $\begin{array}{l}.00235 \\
.00235 \\
.00235 \\
.00235\end{array}$ & $\begin{array}{l}.00205 \\
.00205 \\
.00200 \\
.00200\end{array}$ \\
\hline $\begin{array}{l}1982-1 \\
1982-2 \\
1982-3 \\
1982-4\end{array}$ & $\begin{array}{l}10 \% \\
1 \% \\
7 \%\end{array}$ & $\begin{array}{l}1<81 \\
1<82 \\
1<82 \\
1 / 82\end{array}$ & $\begin{array}{r}1 / 1 / 82 \\
4 / 1 / 82 \\
711 / 82 \\
10 / 1 / 82\end{array}$ & $\begin{array}{l}.03000 \\
.03000 \\
.03000 \\
.03000\end{array}$ & $\begin{array}{l}.01900 \\
.01900 \\
011900 \\
.01900\end{array}$ & $\begin{array}{l}.00711 \\
.00711 \\
.00711 \\
.00711 \\
.00711\end{array}$ & $\begin{array}{l}.00235 \\
.00235 \\
.00235 \\
.002335\end{array}$ & $\begin{array}{l}.00200 \\
.00200 \\
.00200 \\
.00200\end{array}$ \\
\hline $\begin{array}{l}1983-1 \\
1983-2 \\
1983-3 \\
1983-4\end{array}$ & $\begin{array}{l}101 \\
11 \\
4 / \\
71\end{array}$ & $\begin{array}{l}1<82 \\
1<83 \\
1<83 \\
1<83\end{array}$ & $\begin{array}{r}1 / 1 / 83 \\
4 \% 1 / 83 \\
7 / 1 / 83 \\
10 / 1 / 83\end{array}$ & $\begin{array}{l}.03000 \\
.02900 \\
.02900 \\
.02900\end{array}$ & 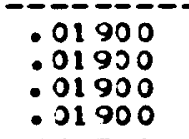 & $\begin{array}{l}.00711 \\
.00711 \\
.00711 \\
.00711 \\
.00711\end{array}$ & $\begin{array}{l}.0-\overline{-}-\overline{0} \\
.00235 \\
.00235 \\
.00235 \\
.00235\end{array}$ & $\begin{array}{l}.00200 \\
.00200 \\
.00200 \\
.00200 \\
.00200\end{array}$ \\
\hline $\begin{array}{l}1984-1 \\
1984-2 \\
1984-3 \\
1984-4\end{array}$ & $\begin{array}{l}10 \% \\
1 \% \\
4 \%\end{array}$ & $\begin{array}{l}1 / 83 \\
1<84 \\
1<84 \\
1<84\end{array}$ & $\begin{array}{r}1 / 1 / 84 \\
4 / 1 / 84 \\
7 / 1 / 84 \\
10 / 1 / 84\end{array}$ & $\begin{array}{l}.02900 \\
.02900 \\
.02900 \\
.02900\end{array}$ & $\begin{array}{r}01900 \\
.01900 \\
.0190 \\
.01900 \\
.01900\end{array}$ & $\begin{array}{l}.00711 \\
.00711 \\
000711 \\
.00711 \\
.00711\end{array}$ & $\begin{array}{l}.00235 \\
.00235 \\
.00235 \\
.00220\end{array}$ & $\begin{array}{l}.00200 \\
.00200 \\
.00200 \\
.00200\end{array}$ \\
\hline $\begin{array}{l}1985-1 \\
1985-2 \\
1985-3\end{array}$ & $\begin{array}{l}10 / \\
1 \% \\
4 \%\end{array}$ & $\begin{array}{l}1<24 \\
1<85 \\
1<85\end{array}$ & $\begin{array}{l}1 / 1 / 85 \\
4 \prime 1<85 \\
7 / 1 / 85\end{array}$ & $\begin{array}{l}.02900 \\
.02800 \\
.02900\end{array}$ & $\begin{array}{l}.01900 \\
.01900 \\
.01900\end{array}$ & $\begin{array}{l}.00711 \\
.00711 \\
.00711\end{array}$ & $\begin{array}{l}.05220 \\
.00220 \\
.00220\end{array}$ & $\begin{array}{l}.00200 \\
.00200 \\
.00200\end{array}$ \\
\hline
\end{tabular}

FIGURE 10

Example of Operating Parameters Summary Output 
$S U M M A R Y$

\begin{tabular}{|c|c|c|c|c|c|c|c|c|c|c|}
\hline $\begin{array}{l}\text { FISCAL } \\
\text { YR-OTR }\end{array}$ & $\begin{array}{l}\text { CALENDAR } \\
\text { START }\end{array}$ & $\begin{array}{r}\text { DATES } \\
\text { END }\end{array}$ & $\begin{array}{l}\text { ORDE } \\
\text { NUMBER } \\
\text { RECEIVED }\end{array}$ & $\begin{array}{l}\text { R INFORMAT } \\
\text { NUMBER } \\
\text { DELAYED }\end{array}$ & $\int_{\text {OEL UNITS }}^{\text {ON }}$ & $\begin{array}{l}\text { ERDA URAR } \\
\text { DURING } \\
\text { PERIOD }\end{array}$ & $\begin{array}{l}\text { VIUM USEO } \\
\text { TOTAL } \\
\text { TO DATE }\end{array}$ & $\begin{array}{l}\text { MET TONS } \\
\text { URANI UM }\end{array}$ & $\begin{array}{l}\text { STOCKPILE } \\
\text { SEP WORK } \\
\text { UNI TS }\end{array}$ & $\begin{array}{l}\text { AVERAGE } \\
\text { ASSAYY }\end{array}$ \\
\hline $\begin{array}{l}1977-2 \\
1977-3 \\
1977-4\end{array}$ & 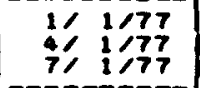 & $\begin{array}{r}411>77 \\
71,1<77 \\
101,1177\end{array}$ & $\begin{array}{l}19 \\
17 \\
22\end{array}$ & $\begin{array}{l}0 \\
0 \\
0\end{array}$ & $\begin{array}{l}0: 0 \\
0: 0 \\
0: 0\end{array}$ & $\begin{array}{r}2196 . \\
-244 \\
-1052 .\end{array}$ & $\begin{array}{l}2196 . \\
1952: \\
900\end{array}$ & $\begin{array}{l}11307.3 \\
11721: 4 \\
11682.3\end{array}$ & $\begin{array}{l}44229 \cdot 3 \\
45220 \cdot 3 \\
44793.6\end{array}$ & $\begin{array}{l}.02807 \\
.02781 \\
.02770\end{array}$ \\
\hline $\begin{array}{l}1978-1 \\
1978-2 \\
1978-3 \\
1978-4\end{array}$ & 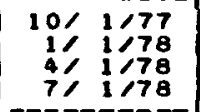 & $\begin{array}{r}11 \\
4 / 78 \\
71 \\
1 / 78 \\
10 / 1 / 78\end{array}$ & $\begin{array}{l}18 \\
19 \\
18 \\
21\end{array}$ & $\begin{array}{l}0 \\
0 \\
0 \\
0\end{array}$ & $\begin{array}{l}0: 0 \\
0: 0 \\
0: 0 \\
0: 0\end{array}$ & $\begin{array}{r}1144 . \\
-1279 \\
-1533 \\
-1534\end{array}$ & $\begin{array}{r}2044 \\
755 \\
212 \\
-1322\end{array}$ & $\begin{array}{l}11955.0 \\
12166.4 \\
12485.0 \\
12475.1\end{array}$ & $\begin{array}{l}45335.2 \\
45742.5 \\
46699: 9 \\
45743.3\end{array}$ & $\begin{array}{l}.02750 \\
.02735 \\
.02726 \\
.02691\end{array}$ \\
\hline $\begin{array}{l}1979-1 \\
1979-2 \\
1979-3 \\
1979-4\end{array}$ & $\begin{array}{r}101 / 78 \\
111 / 79 \\
111 / 79\end{array}$ & $\begin{array}{r}1 / 1 / 79 \\
4 \prime 1 / 79 \\
71 \\
10 / 1 / 79\end{array}$ & $\begin{array}{l}16 \\
21 \\
24 \\
23\end{array}$ & $\begin{array}{l}0 \\
0 \\
0 \\
0\end{array}$ & $\begin{array}{l}0.0 \\
0: 0 \\
0: 0 \\
0: 0\end{array}$ & $\begin{array}{l}-864 \\
-3556: \\
-2377 \\
-2255:\end{array}$ & $\begin{array}{l}-2186 \\
-5742 \\
-6119 \\
-8374\end{array}$ & $\begin{array}{l}12869.3 \\
12750: 3 \\
12600: 4 \\
12266: 0\end{array}$ & $\begin{array}{l}46245.6 \\
45823.7 \\
45216: 1 \\
42940.7\end{array}$ & $\begin{array}{l}.02656 \\
.02656 \\
.02654 \\
.02612\end{array}$ \\
\hline $\begin{array}{l}1980-1 \\
1980-2 \\
1980-3 \\
1980-4\end{array}$ & $\begin{array}{r}10 \\
113790 \\
4 \% 1380 \\
711800\end{array}$ & $\begin{array}{r}1 / 1<80 \\
4 \% 1 / 80 \\
71 / 80 \\
10 / 1 / 80\end{array}$ & $\begin{array}{l}20 \\
23 \\
22 \\
21\end{array}$ & $\begin{array}{l}0 \\
0 \\
0 \\
0\end{array}$ & $\begin{array}{l}0.0 \\
0: 0 \\
0: 0 \\
0.0\end{array}$ & $\begin{array}{l}-2636 \\
-1634: \\
-2108: \\
-6069\end{array}$ & 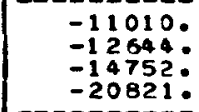 & $\begin{array}{l}12453.8 \\
12267.6 \\
11922.8 \\
12187.6\end{array}$ & $\begin{array}{l}43368.3 \\
42106.6 \\
40438.8 \\
39384.1\end{array}$ & $\begin{array}{l}.02604 \\
.02580 \\
.02560 \\
.02485\end{array}$ \\
\hline $\begin{array}{l}1981-1 \\
1981-2 \\
1981-3 \\
1981-4\end{array}$ & 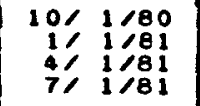 & $\begin{array}{r}1 \% \\
4 / 1 / 81 \\
73,1 / 81 \\
10 / 1 / 81\end{array}$ & $\begin{array}{l}20 \\
28 \\
30 \\
30\end{array}$ & $\begin{array}{l}2 \\
6 \\
7 \\
7\end{array}$ & $\begin{array}{r}188.1 \\
1552.5 \\
1339.8 \\
1451.3\end{array}$ & $\begin{array}{r}-832 \\
-67 \\
-727 \\
-6684:\end{array}$ & $\begin{array}{l}-21653 \\
-21720 \\
-22447 \\
-29131 .\end{array}$ & $\begin{array}{l}12328.4 \\
11623.2 \\
11386.2 \\
11267.1\end{array}$ & $\begin{array}{l}38871.2 \\
36085: 6 \\
35061: 5 \\
33415.6\end{array}$ & $\begin{array}{l}.02447 \\
.02424 \\
.02413 \\
.02359\end{array}$ \\
\hline $\begin{array}{l}1982-1 \\
1982-2 \\
1982-3 \\
1982-4\end{array}$ & $\begin{array}{r}10 / 1 / 81 \\
1 / 1 / 82 \\
4 \prime, 1 / 82 \\
7 / 1 / 82\end{array}$ & $\begin{array}{r}1 / 1 / 82 \\
4 \prime 1 / 82 \\
71 / 1 / 82 \\
10 / 1 / 82\end{array}$ & $\begin{array}{l}27 \\
27 \\
32 \\
36\end{array}$ & $\begin{array}{r}2 \\
7 \\
15 \\
16\end{array}$ & $\begin{array}{r}591.0 \\
2843.9 \\
4125.9 \\
4633.2\end{array}$ & $\begin{array}{r}-3656: \\
1994: \\
2138: \\
-10690\end{array}$ & $\begin{array}{l}-32797 \\
-30813 \\
-28675 \\
-39365\end{array}$ & $\begin{array}{l}11379.5 \\
10924.0 \\
10837.1 \\
11037.4\end{array}$ & $\begin{array}{l}33055.5 \\
30788.4 \\
29976.8 \\
29741.7\end{array}$ & $\begin{array}{l}.02335 \\
.02289 \\
.02265 \\
.02231\end{array}$ \\
\hline $\begin{array}{l}1983-1 \\
1983-2 \\
1983-3 \\
1983-4\end{array}$ & $\begin{array}{r}10 / 1 / 82 \\
1 \%, 83 \\
4 \prime 1 / 83 \\
7 / 1 / 83\end{array}$ & $\begin{array}{l}1 / 83 \\
411 / 83 \\
71 / 1 / 83 \\
101,1 / 83\end{array}$ & $\begin{array}{l}37 \\
45 \\
45 \\
50\end{array}$ & $\begin{array}{l}18 \\
22 \\
26 \\
36\end{array}$ & $\begin{array}{r}4411.4 \\
9806.3 \\
13068.9 \\
14126.4\end{array}$ & $\begin{array}{r}-4841 . \\
7094: \\
5638 \\
-11562\end{array}$ & $\begin{array}{l}-44206 . \\
-37112 \\
-31474 \\
-43036\end{array}$ & $\begin{array}{l}11280.8 \\
10520.0 \\
105112.7 \\
10979.9\end{array}$ & $\begin{array}{l}29850.4 \\
26426: 2 \\
26149.8 \\
26975.4\end{array}$ & $\begin{array}{l}.02208 \\
.02144 \\
.02133 \\
.02119\end{array}$ \\
\hline $\begin{array}{l}1984-1 \\
1984-2 \\
1984-3 \\
1984-4\end{array}$ & $\begin{array}{rl}10 / 1 / 83 \\
1 / 1 / 84 \\
4 \prime 1 / 84 \\
71 & 1 / 84\end{array}$ & $\begin{array}{r}1 / 1 / 84 \\
4 \prime \\
7 / 84 \\
10 / 1 / 84 \\
10 / 1 / 84\end{array}$ & $\begin{array}{l}59 \\
69 \\
75 \\
81\end{array}$ & $\begin{array}{l}42 \\
52 \\
57 \\
65\end{array}$ & $\begin{array}{l}13611.7 \\
20851: 5 \\
24078: 1 \\
26234.6\end{array}$ & $\begin{array}{r}-5152 . \\
7936 \\
5616 \\
-13847\end{array}$ & $\begin{array}{l}-48199 \\
-40252 \\
-34636 \\
-48483\end{array}$ & $\begin{array}{l}11184.8 \\
10454.8 \\
10507.4 \\
1.0992 .9\end{array}$ & $\begin{array}{l}27620.1 \\
24888.6 \\
24646.1 \\
25446.4\end{array}$ & $\begin{array}{l}.02124 \\
02082 \\
002066 \\
.02051\end{array}$ \\
\hline $\begin{array}{l}1985-1 \\
1985-2 \\
1985-3\end{array}$ & $\begin{array}{r}10 / 1 / 84 \\
1 /, 1 / 85 \\
4,1 / 85\end{array}$ & $\begin{array}{l}1 / 1 / 85 \\
4 \prime 1 / 85 \\
711 / 85\end{array}$ & $\begin{array}{l}86 \\
95 \\
97\end{array}$ & $\begin{array}{l}69 \\
72 \\
72\end{array}$ & $\begin{array}{l}26134.6 \\
36735.9 \\
40446.8\end{array}$ & $\begin{aligned}-54211 \\
10144: \\
6042\end{aligned}$ & $\begin{array}{l}-53904 \\
-43750 \\
-37713 .\end{array}$ & $\begin{array}{l}11483.9 \\
10899.4 \\
10933.1\end{array}$ & $\begin{array}{l}26641.8 \\
24147.4 \\
23777.8\end{array}$ & $\begin{array}{r}.02053 \\
.02004 \\
0101984 \\
\end{array}$ \\
\hline TOTALS & $111 / 77$ & $7 / 1 / 85$ & 1273 & 593 & 246231.7 & & & & & \\
\hline
\end{tabular}

FIGURE 11

Example of Important Calculational Summary 


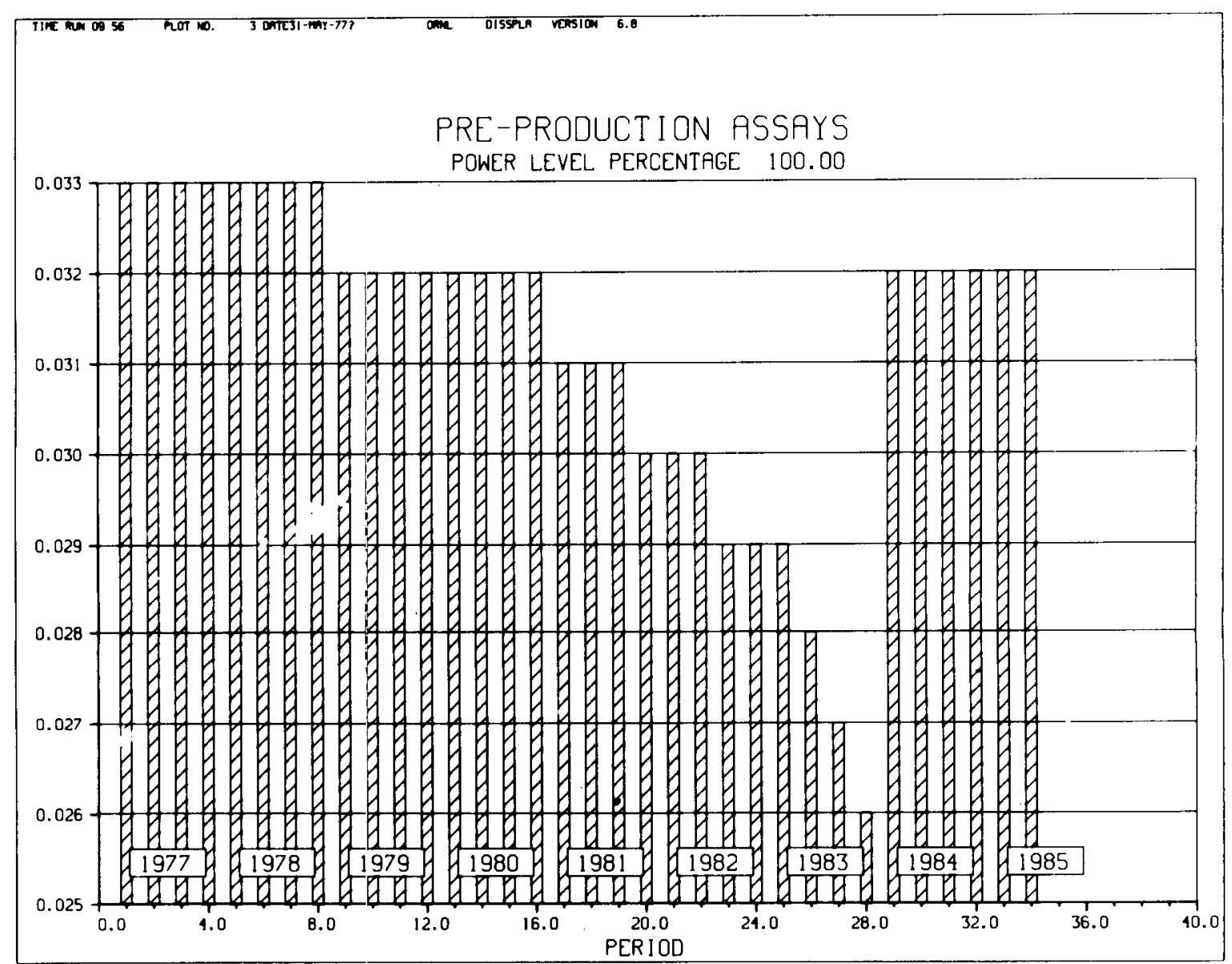

FIGURE 12

Example of Assay Plot 


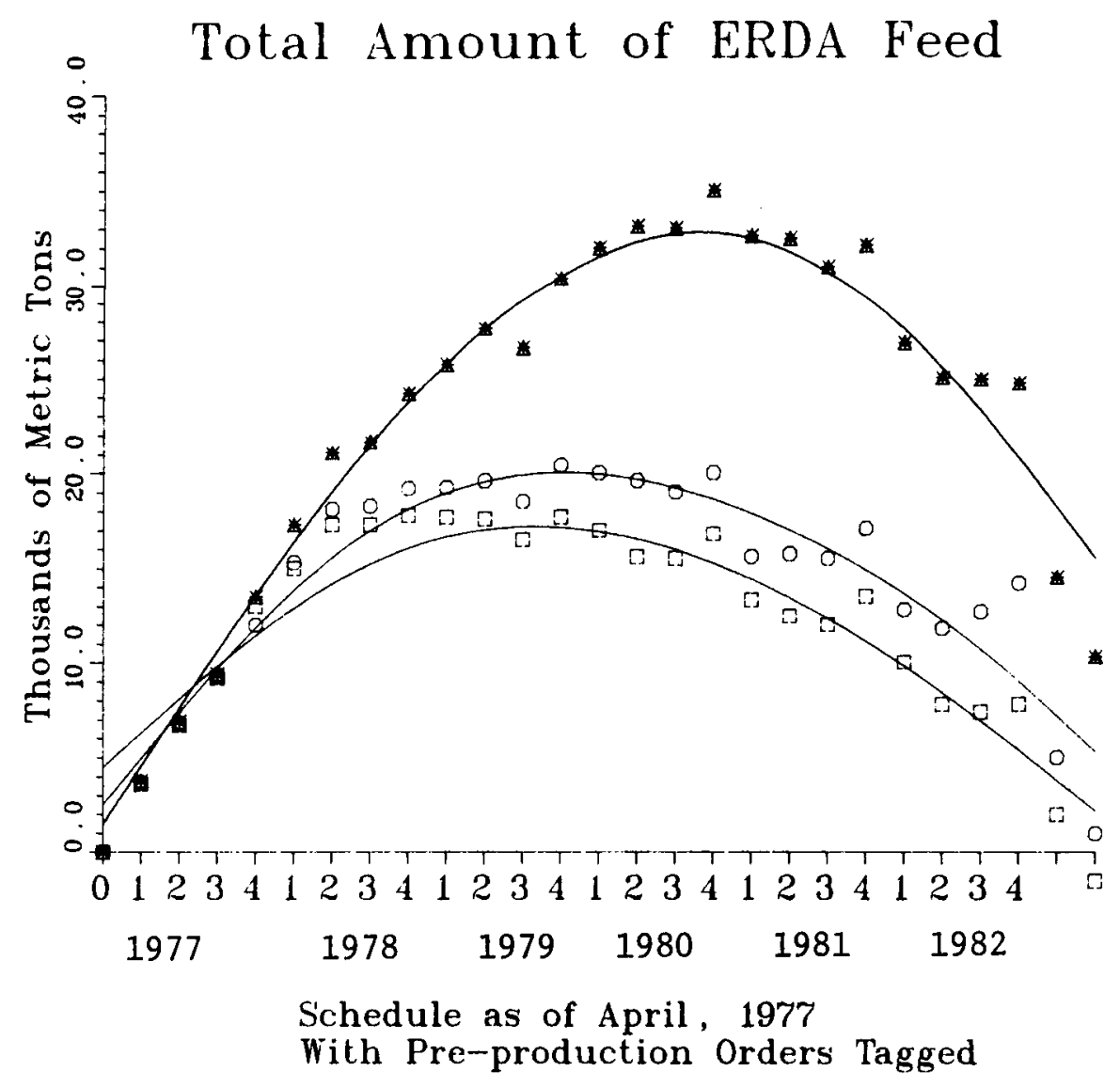

FIGURE 13

Example Plot of ERDA Feed Requirements 


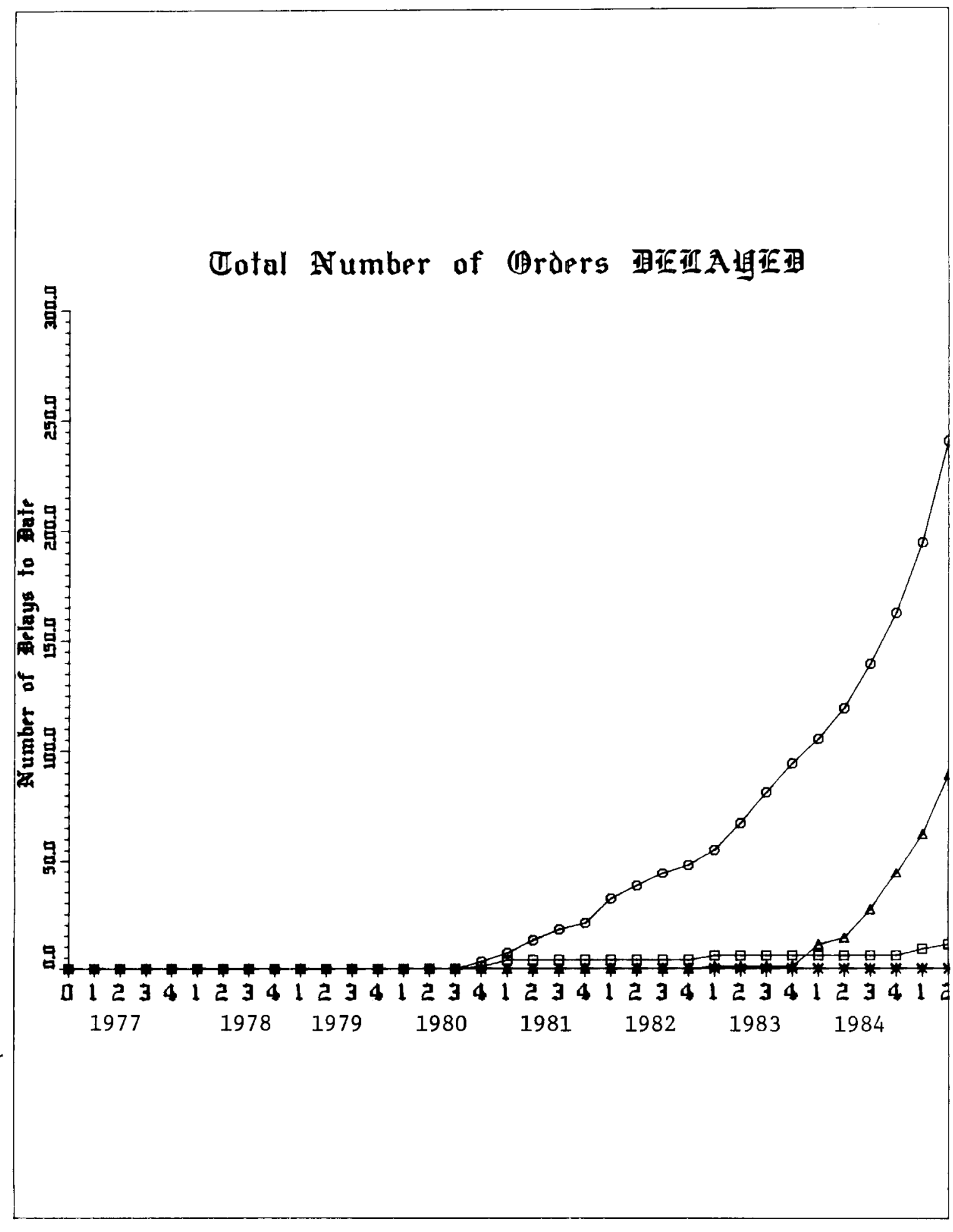

FIGURE 14

Example of Delay Plot 
5. FUTURE WORK

This report is a summary of the current status of the set of programs referred to as SCOPE. Work is planned and continuing in the following areas :

1) A user's manual for SCOPE (Phase I) is being prepared;

2) The scheduling algorithms area is being improved to reduce the time required per calculation, thus allowing more heuristic calculations and possibly some optimization;

3) The number and type of plants that can be handled are being increased; and

4) More graphical capabilities are being included to simplify data presentation. 


\section{CONCLUSIONS AND RECOMMENDATIONS}

A summary description of the current status of the package of computer programs, SCOFE, which is being developed to provide an aid in improving cascade complex production efficiency by refining, operating, and scheduling procedures, has been presented in this report. One major scheduling decision is concerned with the sequence and timing of preproduction assays which will minimize use of ERDA feed and assure the maximum contingency for filling orders. This program can be used to determine the appropriate operating schedule to provide one solution to this problem.

The SCOPE programs can now compare various approaches to running a complex (three or more plants). Using these calculations, the user can select a preproduction schedule that will minimize the chance of delays under a low power contingency case over several years. The selection of the contingency plan must be given some thought. For example, is a $60 \%$ power case the one that should be used for planning purposes?

At this time, some attention should be given to standardizing the labeling of the requirements data files. The authors recommend that the data sets be given alphabetic titles plus dates of creation. With this type of identification, a user could simply request an order tape created $7 / 10 / 77$ and that data can be acquired with minimum effort. Presently, no formal nomenclature exists and communications are hampered. We further suggest, at this time, that recipients of this report review the example program output and provide any comments about its completeness, content, or format. 
REFERENCES

1. Tunsta11, J. N., "The General Productivity Code: Productivity Optimization of Gaseous Diffusion Cascades, The Programmer's Guide," UCCND/CSD-11, Union Carbide Corporation, Oak Ridge, TN (May 1975).

2. "DISSPLA - Display Integrated Software System and Plotting Language," Integrated Software Systems Corporation, San Diego, California (Copyrighted 1970). 
ษ 


\section{ACKNOWLEDGMENTS}

This work was requested by the Interplant Operating Committee and funded by the Operations Analysis and Planning Division. The authors would like to express their appreciation to M. S. Ginsburg who provided valuable counsel in the course of this work. The authors would also like to thank Teri Stanton and Normel Hodges for their assistance in grammatical editing and typing. 
DISTRIBUTION

1-46. Computer Sciences
A. A. Brooks
H. P. Carter
K. E. Cross (10)
R. C. DeLozier (20)
R. W. Henderson
D. M. Kelleher (10)
N. H. Van Wie
CSD Library, K-1007
CSD Library, ORNL

47-52. Operations Anal. \& Planning
J. T. Bradbury III
A. de 1a Garza
M. S. Ginsburg
T. R. Lemons
S. A. Levin
L. P. Pasquier

53-57. Operations
58-60. ORGDP Technical Services

D. S. Napolitan

61-64. ORGDP Library

65. ORGDP Records - RC

66-67. Paducah P1ant

R. A. Green

C. W. Walter

M. P. DeLozier

E. L. Hannahs

J. F. Hudson

K. W. Sommerfeld

L. E. Wheeler

EXTERNAL DISTRIBUTION

68-73. M. M. Dare, United States Energy Research and Development Administration, P. O. Box E, Oak Ridge, Tennessee 37830

74. J. S. Murre11, Goodyear Atomic Corporation, P. 0. Box 628, Piketon, Ohio 45661

75. L. D. Reynolds, International Atomic Energy Agency, Karntner Ring 11, P. 0. Box 645, A-1011 Vienna, Austria, Europe

76-102. Technical Information Center, United States Energy Research and Development Administration, P. 0. Box 62, Oak Ridge, Tennessee 37830

103. F. E. Woltz, Goodyear Atomic Corporation, P. 0. Box 628, Piketon, Ohio 45661 